\title{
Expanding Trades in Late Ottoman Cairo and Damascus
}

The rising appeal of Islamic collectibles in Europe and America set a pattern among those who visited, or sojourned in, the Middle East: that of procuring antiques locally and transporting them back home. The sought-after artefacts were mostly secured through formal trade. From the midnineteenth century onwards, all indicators are that Cairo and Damascus became active market-places for Islamic artworks, although the information is fragmentary and unevenly distributed. Evidence on antique dealing does exist for fin-de-siècle Egypt, but it mostly covers "Egyptian" objects, by which are meant the Ancient pieces obtained primarily at excavations, but also at the villages closest to the ruins. ${ }^{1}$ No comparable documentation is available for Islamic artefacts produced under Fatimid, Ayyubid, Mamluk, or Ottoman rule. Yet, some evidence for Cairo, as well as for Damascus, can be retrieved from a heterogeneous array of sources: Western travelogues, Arabic encyclopaedias, scholars' papers, museum archives, private correspondence, and photography. The following is an attempt to piece together this scattered information. At the very least, the material allows for the outlining of significant timelines, primary locales, typical providers and characteristic objects; it also offers some leads on the provenance of the objects.

As far as can be established, the development of a trade in historic goods followed quite distinct routes in Cairo and in Damascus. In Egypt, the market was mainly geared towards archaeological

1 Frederik Hagen and Kim Ryholt, The Antiquities Trade in Egypt 1880-1930, The H.O. Lange Papers (Copenhagen: Royal Danish Academy of Sciences and Letters, 2016). findings brought up by digs; Islamic artworks represented a marginal trade in comparison. Stock of objects from the Islamic period seems indeed more limited in Cairo than in Damascus. As a matter of fact, established dealers specialising in Islamic artworks emerged at a later stage in the Egyptian city. In contrast, the Syrian capital housed traders in Islamic curios since at least the 185 os, and it remained for many decades the most renowned place for the abundance and quality of available antiques, whether arms, ceramics, metalwork, or indeed architectural salvage. Most Syrian travelogues include a chapter on the riches of the bazaars, the lavish objects on display, and the opulence of Damascene merchants. ${ }^{2}$ Products, old and new, ranged from locally-made "silks, and embroidered scarfs," to "carpets and curiously inlaid ornaments and caskets from Persia; shawls from Hind and Cashmere; weapons of every form and character, richly ornamented with gold and gems." 3 The distinction between authentic antiques and Revival items appears rarely in the sources; both seem to have catered to the same clientele. A segment of the commodities came through the pilgrimage caravans from Baghdad and further East; annually these conveyed thousands of people to Damascus, who were eager to join the official convoy placed under the protection of the Ottoman sultan. They brought with them possessions to trade en route to, or back from, Mecca. Eastern goods of myriad provenances circulated

2 For an example of the narrative, Jean-Jacques Bourassé, La Terre-Sainte, voyage dans l'Arabie Pétrée, la Judée, la Samarie, la Galilée et la Syrie (Tours: A. Mame et fils, 186o), 427 .

3 Josias Leslie Porter, Five Years in Damascus: Including an Account of the History, Topography, and Antiquities of that City; with Travels and Researches in Palmyra, Lebanon, and the Hauran (London: J. Murray, 1855), I: 31.

(C) MERCEDES VOLAIT, 2021 | DOI:10.1163/9789004449886_004 
on the routes to the Holy City. ${ }^{4}$ The advent of steamship meant that after the 1840 s there was a reduced number of caravans, but transit trade continued to be important to Damascus' economy, even after imported European goods dominated the commercial flows. ${ }^{5}$ The city remained a hub for exchanging used objects. In the hierarchy of Middle Eastern bazaars proposed by a tourist guide in 1907, Damascus still undoubtedly came first, while the Cairene souks were considered "inferior even to those of Constantinople." ${ }^{6}$

\subsection{Antique Dealing and Dealers in Cairo}

An early mention of the trade in second-hand commodities in late Ottoman Cairo appears in the fifth edition of the classic Account of the Manners and Customs of the Modern Egyptians, ${ }^{7}$ written in 1833-35 by Edward William Lane after an extended stay in the city. The text was expanded widely in 1860 by his nephew Edward Stanley Poole based on the author's original notes. Among the additions, one note brings to light the practice of auctioning second-hand wares or fabric in the streets of Cairo:

4 John Wilson, The Lands of the Bible, Visited and Described in an Extensive Journey Undertaken with Special Reference to the Promotion of Biblical Research and the Advancement of the Cause of Philanthropy (Edinburgh: William Whyte \& Co, 1847), I: 147-48; Marcus Milwright,"Trade and the Syrian Hajj between the 12th and the early 2 oth centuries", in The Hajj: Collected Essays, eds. Venetia Porter and Liana Saif (London: The Trustees of the British Museum, 2013), 28-35.

5 James Reilly, "Damascus Merchants and Trade in the Transition to Capitalism," Canadian Journal of history XXVII (April 1992): 1-27.

6 Eustace Alfred Reynolds-Ball, Cairo of To-day: a Practical Guide to Cairo and the Nile (London: Adam and Charles Black, 1907), 71.

7 Edward William Lane, Account of the Manners and Customs of the Modern Egyptians Written in Egypt during the Years $1833-5$, partly from notes made during a former visit to that country in the years $1825,-26,-27$ and -28 , edited by his nephew, Edward Stanley Poole (London: J. Murray, 186o), 317. The observation does not appear in previous editions.
In many of the sooks (bazaars) in Cairo auctions are held on stated days, once or twice a week. They are conducted by "dellâls," (or brokers), hired either by private persons who have anything that they wish to sell in this manner, or by shopkeepers; and the purchasers are of both these classes. The "dellâls" carry the goods up and down, announcing the sums bidden with cries of "Harag" or "haraj" etc.

The word dallāl comes from the Arabic verb Dalla, meaning "to show." According to the Lanes, the dallāl (pl. dallālīn) was a crier who loudly advertised second-hand goods for sale in Cairo streets, an equivalent to the practice of vendre à l'encan in France. Until the 18oos, the dallālin were exclusively Turkish; the function was opened to Egyptians only after Mehmed Ali Pasha seized power in $1804 .^{8}$

John Frederick Lewis, the British artist who lived in Cairo from 1841 to 1851 , composed a colourful depiction of a scene that perfectly matches Lane's written description. ${ }^{9}$ (Fig. 35) According to the architectural setting of the watercolour, the action takes place in the vicinity of the Khan al-Khalili, a large caravanserai that gave its name to the central commercial area of historic Cairo. The Dutch artist Willem de Famars Testas (1834-96), who sojourned in Egypt in 1858-60, and visited again in 1868, also remarked on the presence of Cairene criers ("crieurs publics"), populating the passageways of the Khan al-Khalili every Monday and Thursday. This is how one could secure "interesting objects or curiosities," according to Émile Prisse d'Avennes. ${ }^{10}$

8 André Raymond, Artisans et commerçants au Caire au XVIII ${ }^{e}$ siècle (Damas: Presses de l'Ifpo, 1973) II: chapter XI [https://books.openedition.org/ifpo/461o], accessed 13 March 2021.

9 James Parry, Orientalist Lives, Western Artists in the Middle East, 1830-1920 (Cairo: AUC Press, 2018), 151.

"Le journal de voyage de Willem Famars de Testas, 1868," Maarten J. Raven, trans., in Album de voyage au pays du Levant, exhibition catalogue (Paris: RMN, 1993), $100-01$. 


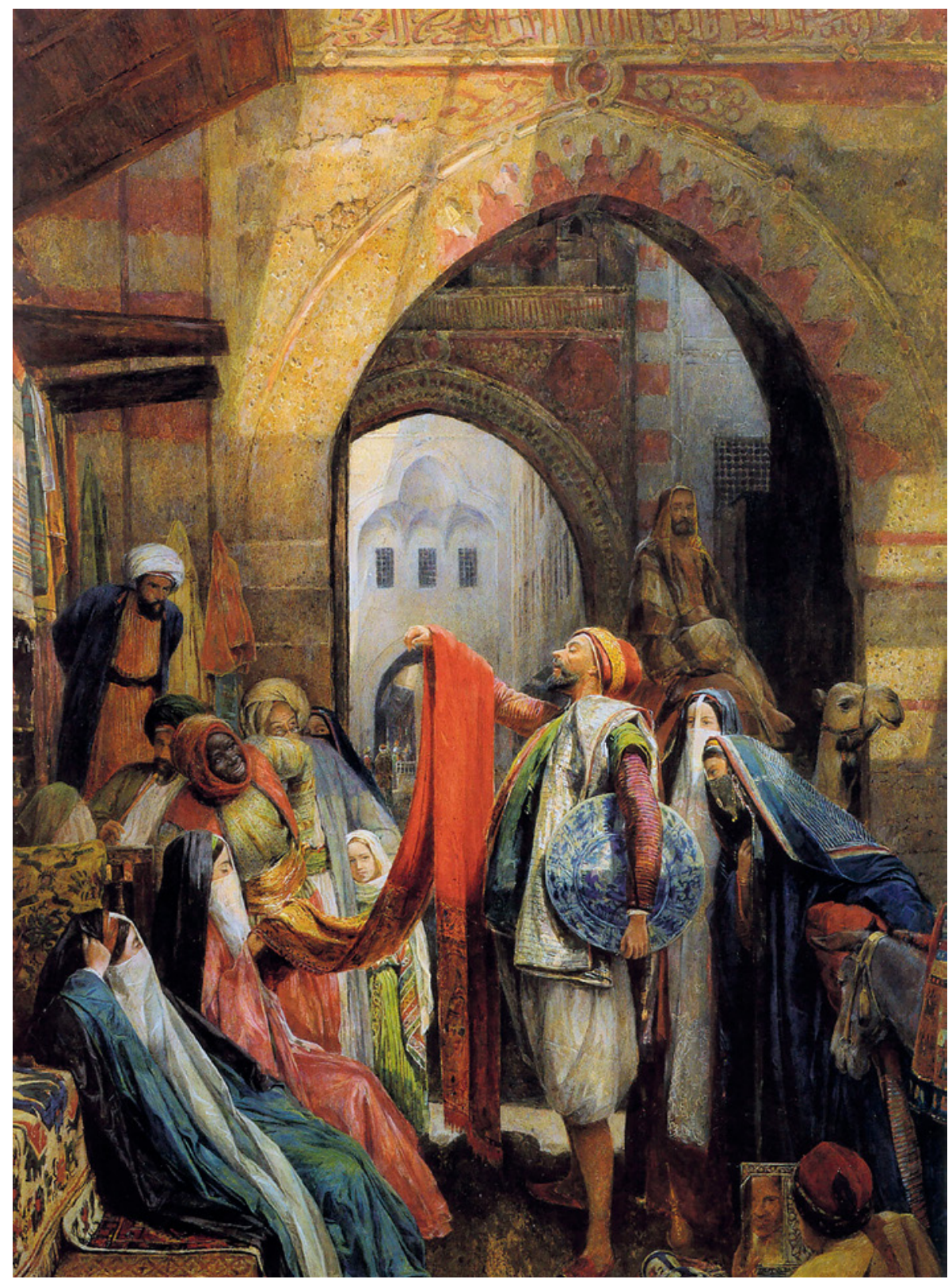

FIGURE 35 John Frederick Lewis, A Cairo Bazaar; The Dellál, 1875. Watercolour. $67.5 \times 51 \mathrm{~cm}$ CAIRO, THE SHAFIK GABR COLLECTION

The addition of the paragraph on the dallāin in the 1860 edition of Lane's Manners and customs may well correspond to the rising Western interest in acquiring "Oriental curiosities," as they came to be known in the literature and sources. It also testifies to the permanence of Ottoman practices in Khedivial Egypt, and the continuity well into the nineteenth century of a particular way of trading second-hand commodities.

Listings of professional and commercial addresses in Cairo do not register any names and locations of traders in antiques before 189o, whether one searches under antiquaires (antique dealers) or négociants de curiosités (dealers in 
curiosities).${ }^{11}$ Early guides released in 1868 record merchants operating as importers or exporters of all types of goods, the only specified trade being, significantly, that of nouveautés (the latest fashion), from Paris and London. ${ }^{12}$ Antiques were still not common currency, nor of particular interest to anyone. The first tourist guidebook mentioning antique dealers in Cairo is Baedecker's sixth German edition, dated $1906 .{ }^{13}$ However, it should not be inferred from this that no antique dealing occurred prior to this date. In a watercolour of historic Cairo's main thoroughfare by Louis-Vincent Fouquet (1803-1863), a shop of significant size selling blue-and-white china, some of which may be old, can be spotted. ${ }^{4}$ (Fig. 36 ) The most prominent dealer in Oriental wares, both old and modern, is said to have started operating in 188 o. Born in Smyrna, Joseph Cohen had been working in Syria, before settling in Egypt. The "Turkish and Persian bazaar" that he opened in 1891 in the Khan al-Khalili gained the reputation of being the most expensive, but also the most reliable, in the business, because its owner "rigidly [excluded] anything in the shape of spurious imitations."15 Another prominent dealer, mostly in Egyptian antiquities but occasionally in Islamic artefacts,

11 Four listings have been used here: Stéfano G. Poffandi, Indicateur égyptien administratif et commercial en usage près les ministères, les tribunaux, les administrations de l'État, des banques, etc., (Alexandria: Impr. générale L. Carriere, 1890 and 1896 editions); Annuaire égyptien administratif et commercial (Cairo: G. Teissonnière, 1891); Mario Di S. Mieli, Guide égyptien du Caire, annuaire administratif et commercial (Cairo: Imp. Moussa Roditi, 1899).

12 François Levernay, Annuaire officiel administrative, commercial et industriel, avec les plans du Caire, Alexandrie et Port-Saïd (Alexandria: Imprimerie nouvelle, 1868); J. Millie, Alexandrie d'Égypte et Le Caire, Guides-Bijou (Milan: Civelli, 1868), 136, 141-42.

13 Hagen and Ryholt, The Antiquities Trade, 286.

14 Auctioned by Damien Leclère and Delphine MartinOrts on 26 March 2018 at Drouot Richelieu, Paris (lot 163).

15 Arnold Wright, ed., Twentieth Century Impressions of Egypt (London: Lloyd's Greater Britain Publishing Company, 1909), 376.
Panayotis Kyticas (?-1924), is recorded as active from 1879 (according to his letter-head) or 1890 elsewhere. ${ }^{16}$ Discrepancies in the sources may be due to the fact that some business took place in the privacy of homes rather than in the openness of the bazaar. The dealer of biggest repute in twentieth-century Cairo, Maurice Nahman (1868-1948) - renowned to the point of having inspired a central character in the film The Night of Counting the Years [al-Mummia] by director Shadi Abdessalam (1969), belongs to the former category. Of Macedonian descent, ${ }^{17}$ Nahman started selling antiquities in 1890 as an activity on the side while formally a bank cashier, therefore operating originally from his house; he did not open a showroom until the late 1910s on 27 Madabegh Street (today Sherif St) where he also lived. ${ }^{18}$ (Fig. 37) His trade was perfectly legal; his "Licence for Sale from the Egyptian Museum" was No. 38. As a matter of fact, many dealers in old books and bric- $\grave{a}$-brac still operate from their homes in Cairo today.

There is also evidence that sellers went to the buyers rather than vice versa - again a practice still current in Cairo, possibly because the trade could not and cannot sustain, apart from a few exceptions, the rent, taxes and hiring demanded by a permanent store, or indeed because services at home were much appreciated, as they continue to be to this day. The daughter of a French collector

16 Ann Gunter, A Collector's Journey: Charles Lang Freer \& Egypt (Washington, DC: Freer Gallery of Art: Arthur M. Sackler Gallery, Smithsonian Institution; London: Scala, 2002), 90-1; Hagen and Ryholt, The Antiquities Trade, 229-30.

17 Interview with his grand-daughter, Alessandra Manessaro, 6 March 1996. The first Nahman in Egypt, Matatia Bey Nahman (d. 1870), was a cotton merchant who had looms installed in Mahalla al-Kubra, the largest city in the Nile Delta.

18 "Les Antiquaires égyptiens," L'Art Vivant v (15 January 1929): 99; Hagen and Ryholt, The Antiquities Trade, 25355; Mercedes Volait, “27, rue Madabegh: une mémoire presque enfouie de la vie artistique du Caire d'antan," in Étudier en liberté les mondes méditerranéens: mélanges offerts à Robert Ilbert, eds. Leila Dakhli and Vincent Lemire (Paris: Publications de la Sorbonne, 2016), 179-88. 


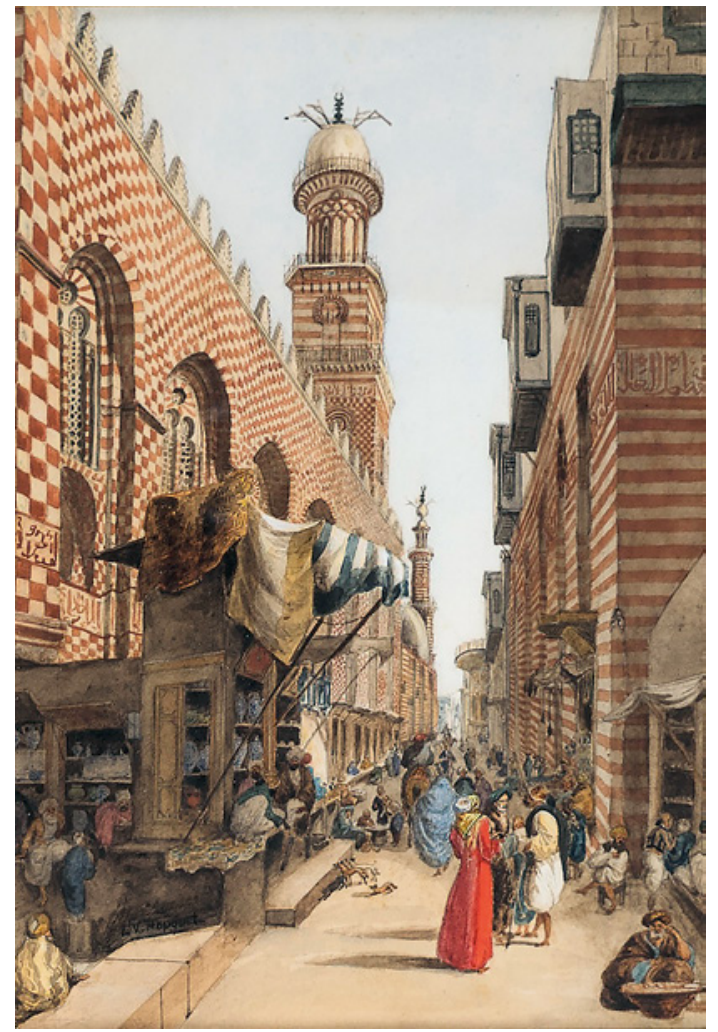

FIGURE 36 Louis Vincent Fouquet, Ruelle animée au Caire, before 1863. [A prominent China dealer on a main thoroughfare in Historic Cairo]. Watercolour on paper. $28 \times 19 \mathrm{~cm}$ DESSINS ANCIENS ET MODERNES, MAISON DE VENTES LECLÈRE, PARIS, 26 MARCH 2018, LOT 163. CURRENT LOCATION UNKNOWN

who resided in the city from 1876 onwards remembered the scene in her diary:

Presque chaque jour, des marchands s'installent dans le vestibule, en démons tentateurs et y étalent leurs richesses. [...] J'avais le loisir d'assister à cette exposition qui n'allait pas sans palabres, repris de jour en jour, où la patience des uns rivalisait avec la persévérance des autres, se terminant par des transactions à nulles autres pareilles. Que c'était donc amusant!19

19 Versailles, private collection, Gabrielle Bompard-de Blignières, $A u$ fil des jours (souvenirs inédits rédigés

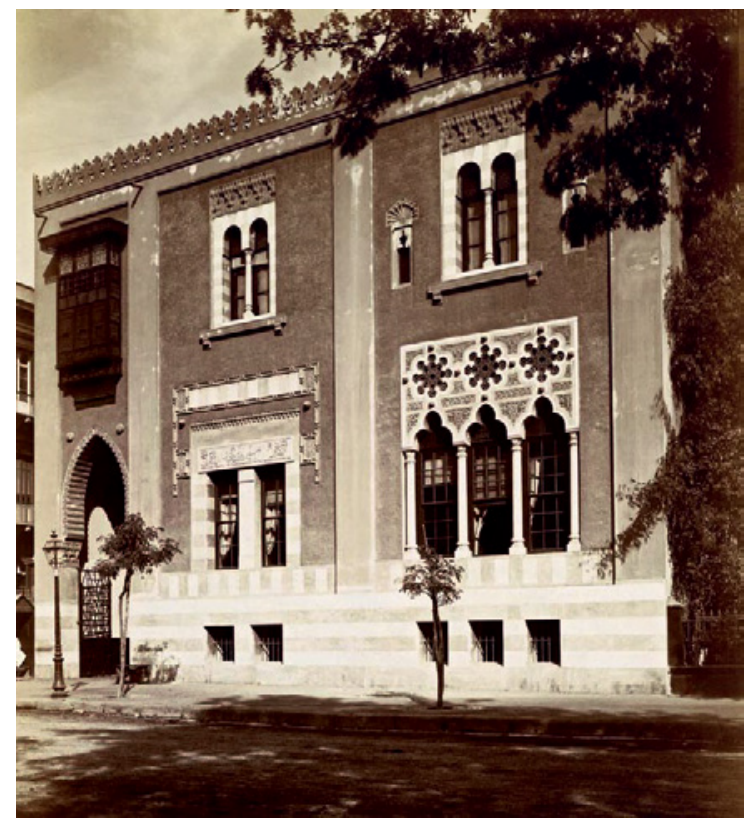

FIgURE 37 Kahil, Hôtel du Cercle artistique, c. 1895.

[The building on 27 Sherif Street in Cairo that housed Maurice Nahman's showroom after 1914]. Albumen print. $16.6 \times 11.8 \mathrm{~cm}$ GENEVA, MUSÉE D'ART ET D'Histoire, A 2006-0029-340

A photograph displaying the very objects bought by this family before their return to France in 1882 (Fig. 38) may illustrate a specific taste, but the image is moreover a good indicator of what was available then to the average collector of Islamic arts. The set is somehow typical: it includes salvaged doors, Indo-Portuguese ivory-inlaid caskets, Damascus chests and stools, kilims, tray-stands, and various pieces of metalwork.

Some previously recorded acquisitions point to transactions directly made on site, right in the object's original setting, in most cases fraudulently. One of the precious enamelled mosque lamps in the collection of Albert Goupil is said to have been obtained by bribing a mosque keeper during

entre 1935 et 1942), 17: Almost every day, merchants settle in the vestibule, as tempting devils, and deploy their riches [...] I could attend this exhibition that did not go without much talking, repeated day after day, during which the patience of one party rivalled with the persistence of the other, and resulted in unprecedented transactions. How amusing this was! [My translation]. 


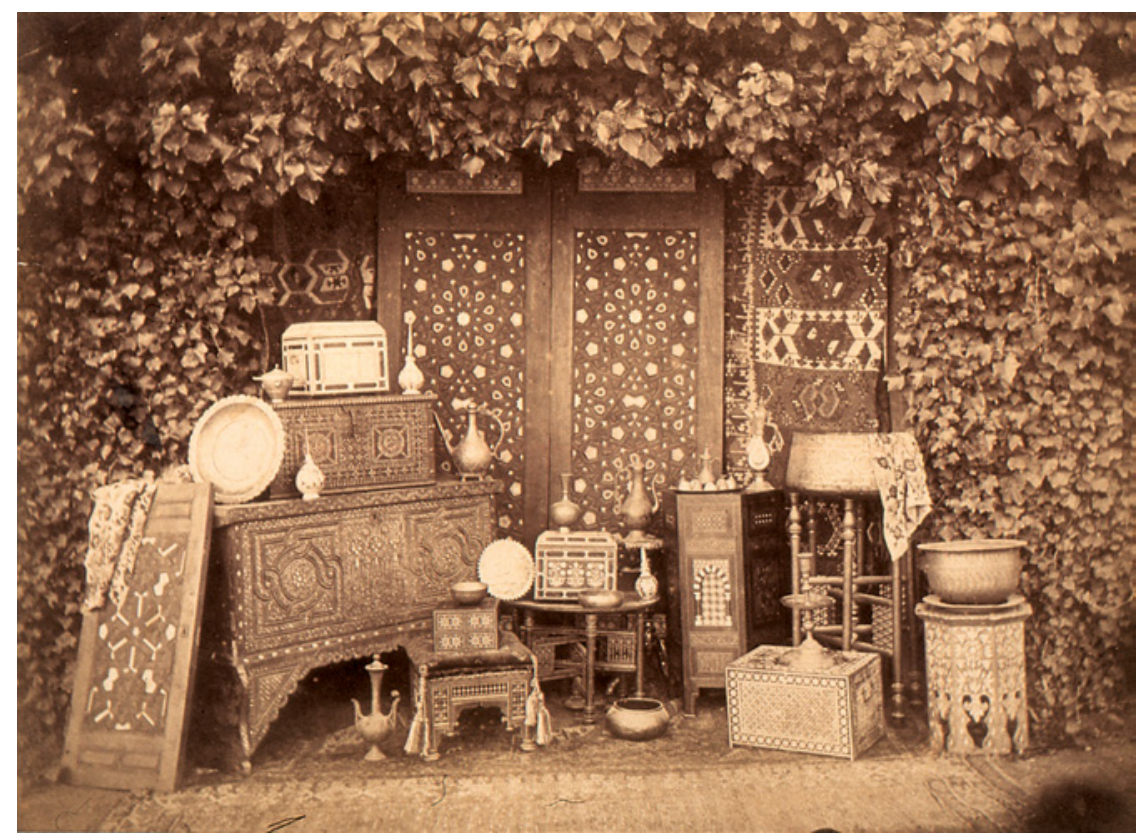

FIGURE 38 Anonymous, Untitled [Objects from the Blignières collection bought between 1876 and 1882 in Cairo]. Albumen print CURRENT LOCATION UNKNOWN

a visit to Cairo in $1868 .^{20} \mathrm{~A}$ few years before, a Mr. Maynard had six stucco stained-glass windows, known as qamariyya or shamsiyya, detached from a mosque named al-Ashrafiyya (either al-Ashraf Barsbay intramuros or its funerary complex in the cemeteries, but possibly indeed the eponymous mosque in Khanqa?) for the purpose of exhibiting them in Paris at the Exposition universelle of 1867. They arrived in pieces and were never displayed, but their remnants were used by Émile Prisse d'Avennes to illustrate a craft that fascinated many because of the vivacious colours used - the very reason why we hear about their later afterlife. ${ }^{21}$

Commercial listings for the last decade of the nineteenth century provide the names of twentyfive established antique dealers in Cairo (see Table 1). As the lists were based on willing declaration, they cannot be considered exhaustive, but they still evidence general traits. Remarkably

20 Michel Zamacois, Pinceaux et stylos (Paris: A. Fayard, 1948), 102.

21 Émile Prisse d'Avennes, L'Art arabe, 278 and III: pl. CXLV. enough, less than one third of the twenty-five names identified overlap with the ones associated with the trade in Egyptian antiquities. Dealing Egyptian art and trading Islamic curios were seemingly not always the same business. Four main specialities can be singled out across the listings: antiques of all periods, Oriental curiosities, Far Eastern curiosities, and rugs. An invoice and a photographic portrait of one merchant, Asadolla Irani, who self-identified as antiquaire [antique dealer] in the listings, suggest that the categories were porous. His letter-head advertised in English and French a business in carpets, arms, gems, coins, embroideries, and ceramics, coming from any place east of Egypt all the way to Japan. However, his trade was described as "curiosities" in the photograph of his shop, and much metalwork can be seen there. (Fig. 39) The name of Asadolla Irani and the Qajar-style imagery on his invoice clearly indicate that he was at least from Iranian descent. (Fig. 40) The carpet dealer Mohamed Hassan Irani may have been of Persian descent as well. There was a long tradition of a Persian presence in Cairo, in particular among merchants and 


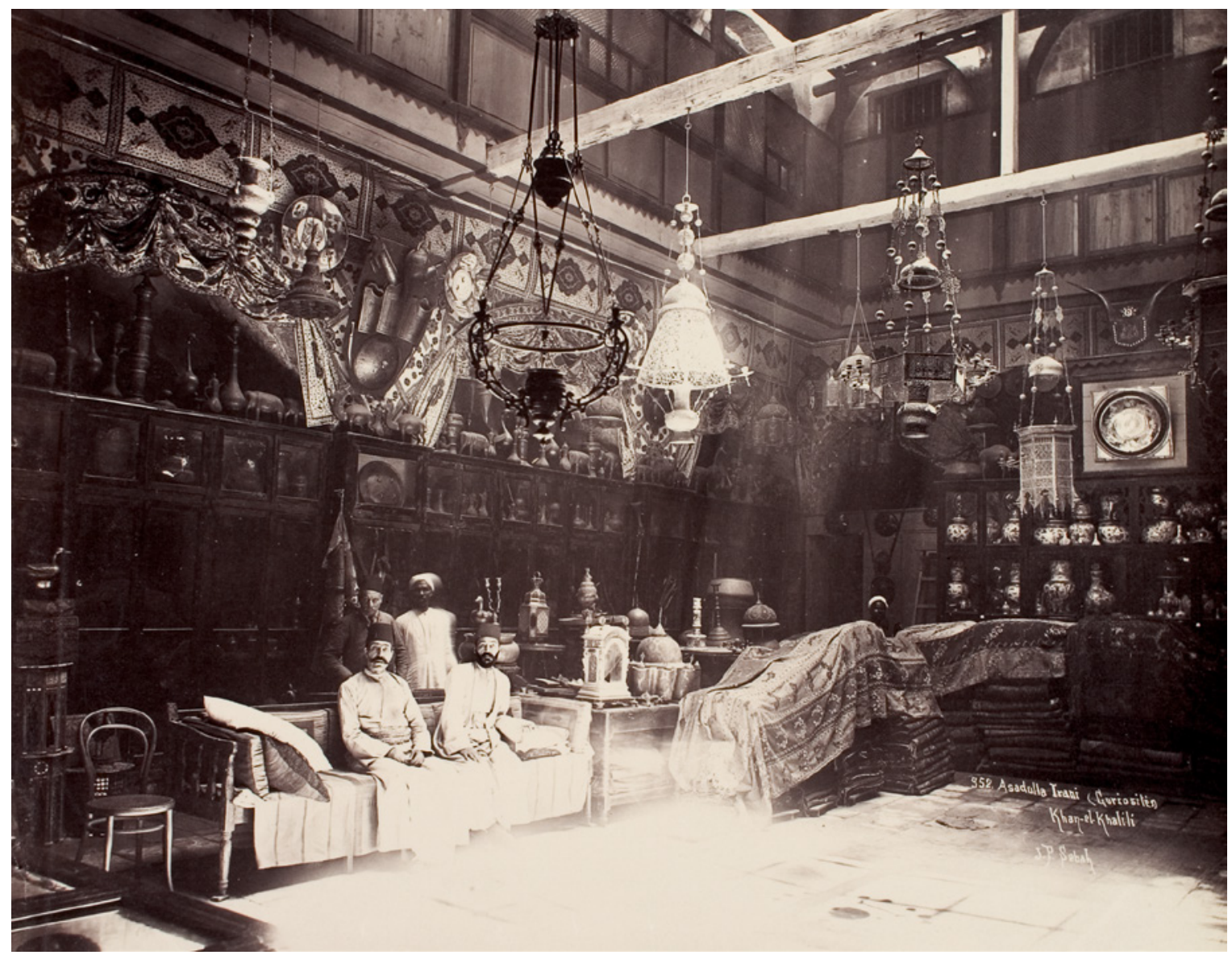

FIg URe 39 Jean Pascal Sebah, Asadolla Irani, Khan al-Khalili (Curiosités), undated [c. 189os]. Albumen print. $20 \times 25 \mathrm{~cm}$ NANTES, BIBLIOTHÈQUE MUNICIPALE, FONDS NORMAND, ÉGYPTE 2 B, 352

craftsmen at the Khan al-Khalili. ${ }^{22}$ The workshop of a relatively late representative of this group, a "Mohamed El-Cherazy"23 [Muhammad al-Shirazi] still stood in 1869 at the entrance of one of its caravanserais. (Fig. 41)

A number of merchants dealt generally in old and new Eastern artefacts. This was the case

22 From even before the Ottoman conquest, see André Raymond, Artisans et commerçants au Caire au XVIII ${ }^{e}$ siècle (Damas: Presses de l'Ifpo, 1973) II, chapter XI passim [https://books.openedition.org/ ifpo/4612], accessed 13 March 2021.

23 Arthur Rhoné, L'Égypte à petites journées. Le Caire d'autrefois. Nouvelle édition (Paris: Société générale d'éditions, 1910), 272. of Joseph Cohen, Elias Hatoun, Paul Philip, E.M. Malluk and Gaspare Giuliana. The business of E.M. Malluk \& Co was in "Old and modern Oriental silks, Furniture: Mouchrabea [sic] Work and Mother of Pearl, Inlaid Tables, Stools, Chairs, Stands, Brackets, etc. Antiquities in Statues, Coins, Jewellery and Arms." ${ }^{24}$ Some were also manufacturers: besides selling Islamic and Egyptian antiques, Elias Hatoun is known to have produced Mamluk Revival works, such as large bronze

24 Advertisement in Mario Di S. Mieli, Guide égyptien du Caire, annuaire administratif et commercial (Le Caire: Imp. Moussa Roditi, 1899), n.p. 


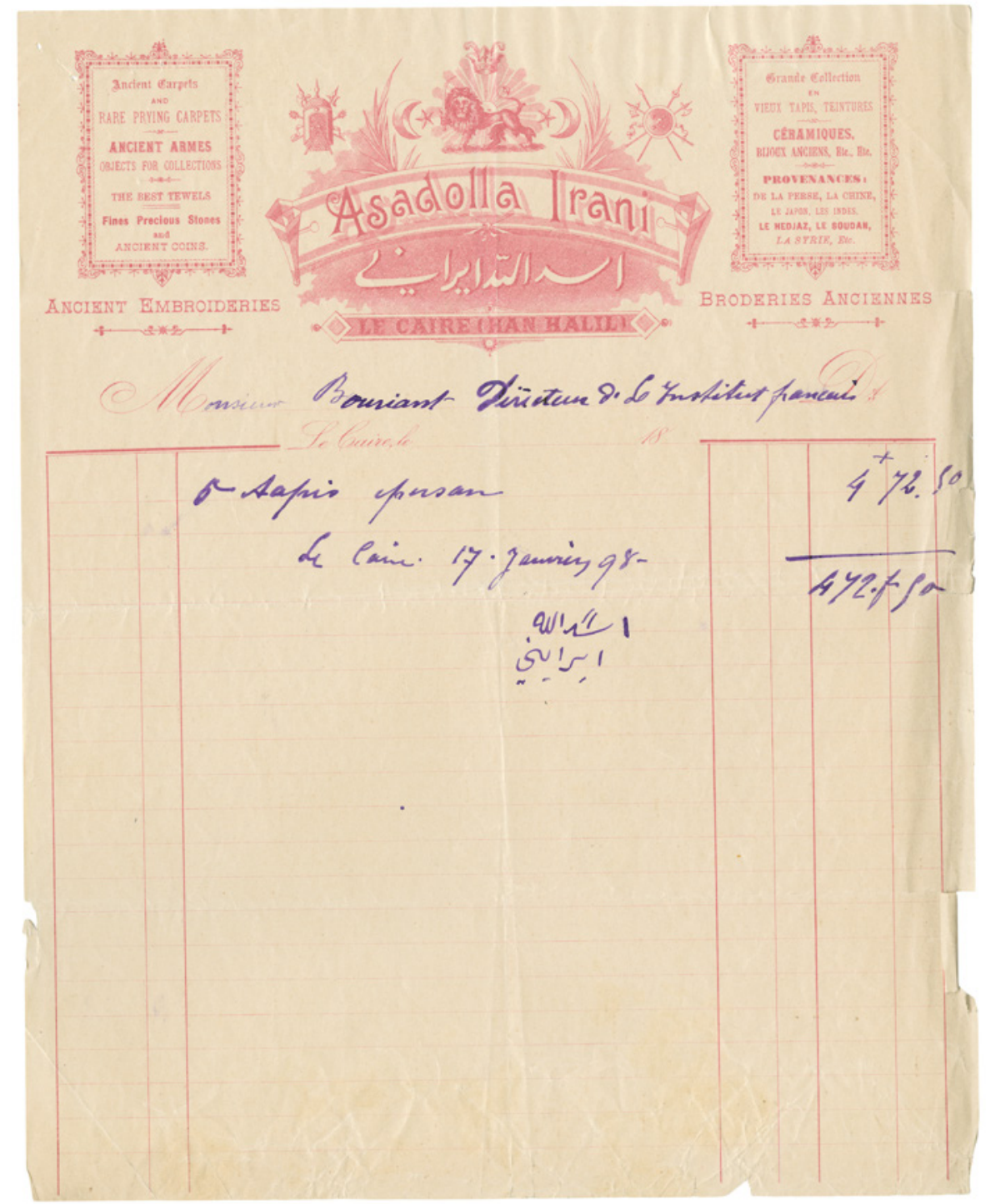

FIGURE 40 Invoice from Asadolla Irani's business in Cairo, 17 January 1898 CAIRO, INSTITUT FRANÇAIS D'ARCHÉOLOGIE ORIENTALE, ARCHIVES ADMINISTRATIVES, MS_2015_01170

doors. ${ }^{25}$ Some of the traders did have backgrounds in handicraft. Active from 1887 to 1909, Paul Philip

25 One is currently in Kuwait, Géza Fehérvári, Sultan Barqūq's Door (Kuwait: Tareq Rajab Museum, 2012) and István Ormos, "The Doors of Sultan Barqūq and their inscriptions," The Arabist 38 (2018): 33-92. A Mamluk style bronze door dated 1906 and bearing the signature of Hatoun's workshop was auctioned at Christie's London on 8 April 2008. advertised his business as "Antiquités-objets d'art. Collections d'étoffes anciennes. Fabrique de meubles de style arabe" [Antiquities-artworks. Collections of old fabrics. Cabinet-making in Arab style]; he is known to have been "originally a French carpenter's apprentice, who had turned to trading in antiquities."26 The cabinet-maker Gaspare

26 Hagen and Ryholt, The Antiquities Trade, 257. 


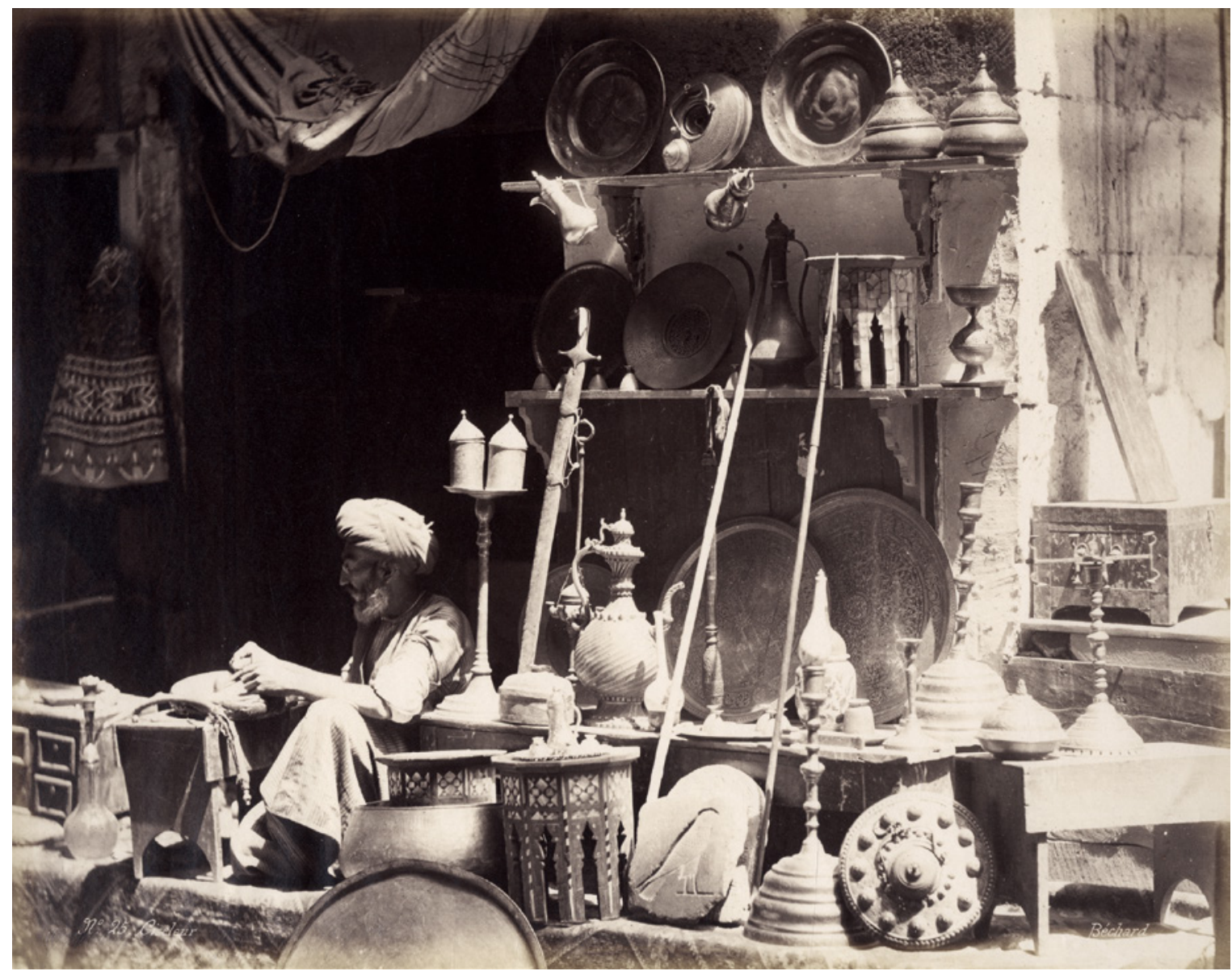

FIGURE 41 Émile Béchard, $N^{\circ}$ 25. Ciseleur [Coppersmith], 1869. The artisan was identified as "Mohammed El-Cherazy, Persan," by Arthur Rhoné in L'Égypte à petites journées 1910: 272. Mounted albumen print. $21 \times 26.8 \mathrm{~cm}$ LEIDEN UNIVERSITY LIBRARIES, SPECIAL COLLECTIONS, ALBUM MM.522, PL. 13

Giuliana also conducted both activities at one time. As the sign on his shop-front recorded by photographer Pascal Sebah (1823-86) in the early 1880s clearly states, his trade was both in cabinetmaking and antique dealing [Ebenista e negoziante antichita]. (Fig. 42) What the shop had on offer comprised a random assortment of old and new handicrafts, mixed with folk art (such as appliqué textiles, known as khayyamiya, and puppet figures); two individual tiles can be spotted on the side of a composite cupboard. Presumably tiles had gone rare and could no more be offered in series or panels. In 1883, Giuliana sold a number of Islamic collectibles to the South Kensington
Museum. ${ }^{27}$ The invoice did present him as an "ébéniste, négociant de mucharabie \& d'antiquités" [cabinet-maker and dealer in lattice windows and antiquities].

The transaction with Giuliana was part of an acquisition campaign carried out in JanuaryMarch 1883 by the Arabist and archaeologist Stanley Lane-Poole (1854-1931) for the museum. The purchases offer a valuable snapshot of existing providers, desired commodities and available goods in Cairo at the time. From Giuliana, Lane-Poole

27 London, Victoria and Albert Museum Archive, Stanley Lane-Poole Nominal file, MA/1/L257. 
TABLE 1 Antique dealers listed in Cairo's commercial listings, 1890-99 and their declared specialities

\begin{tabular}{|c|c|c|}
\hline Dealer & Type of objects & Year(s) of listing \\
\hline Assadola Irani & Antiques & $1890,1891,1896$ \\
\hline Herdan & Antiques & 1890 \\
\hline Kyticas (Panayotis) & Antiques & 189o, 1891, 1896 \\
\hline Pantazi (Elie) & Antiques & 189o, 1891, 1896, 1899 \\
\hline Spiliotis & Antiques & 1890,1896 \\
\hline Tano (Nicolas) & Antiques & $1890,1891,1896$ \\
\hline Assadolla Aga & Oriental curiosities & 189o, 1891, 1896 \\
\hline Joseph Cohen & Oriental curiosities & 189o, 1891, 1896, 1899 \\
\hline Bercovich (J.) & Oriental curiosities & $1890,1891,1896$ \\
\hline Kateb Frères & Oriental curiosities & 1890,1891 \\
\hline Nahabedian (T. \& P.) & Oriental wares & 189o, 1891, 1896, 1899 \\
\hline Nessim D. Sohami & Oriental curiosities & 1891,1899 \\
\hline Bencitrit (Isaac) & Japanese \& Chinese curiosities & 189o, 1891, 1896 \\
\hline Carmona (M.) & Chinese curiosities & 1896,1899 \\
\hline Chellaram (H.) & Indian curiosities & 1890,1896 \\
\hline Pohoomull & Indian curiosities & $1891,1896,1899$ \\
\hline Wassiamul Assomull & Indian curiosities & $1891,1896,1899$ \\
\hline Giuliana (Gaspare) & Antiques and furniture making & 189o, 1891, 1896, 1899 \\
\hline Hatoun (Elias) & Antiques and furniture making & $1890,1891,1896$ \\
\hline Philip (L. Paul) & Antiques and furniture making & 189o, 1891, 1896, 1899 \\
\hline Malluk (E.M.) & Antiques and furniture making & 189o, 1891, 1896, 1899 \\
\hline Assadolla Irani & Rugs & 1899 \\
\hline Colali (K.) & Rugs & 1896 \\
\hline Mohamed Hasan Irani & Rugs & 1891,1896 \\
\hline Mustapha Isaac & Rugs & 1891 \\
\hline
\end{tabular}

SOURCES: STÉFANO G. POFFANDI, INDICATEUR ÉGYPTIEN ADMINISTRATIF ET COMMERCIAL EN USAGE PRÈS LES MINISTÈRES, LES TRIBUNAUX, LES ADMINISTRATIONS DE L'ÉTAT, DES BANQUES, ETC., (ALEXANDRIA: IMPR. GÉNÉRALE L. CARRIERE, 1890 AND 1896 EDITIONS); ANNUAIRE ÉGYPTIEN ADMINISTRATIF ET COMMERCIAL (CAIRO: G. TEISSONNIÈRE, 1891); MARIO Di S. MIELI, GUIDE ÉGYPTIEN DU CAIRE, ANNUAIRE ADMINISTRATIF ET COMMERCIAL (CAIRO: IMP. MOUSSA RODITI, 1899).

bought a "Small Arab room, with meshrebiyehs" (for sixty pounds sterling), further wooden architectural salvage, twelve coloured glass windows and sixty-five tiles. A Gandour Bey (?) sold him objects in ivory; Sebah (most probably the photographer Pascal Sebah) a bronze vase, while various anonymous individuals provided further tiles (170 out of one single house, which equates a surface of about ten square metres). ${ }^{28}$ More tiles were procured from Tano, ${ }^{29}$ a Dimitri (?), (Panayotis)

28 London, Victoria and Albert Archive, Stanley LanePoole Nominal file, MA/1/L257, Purchases made in Cairo for the South Kensington Museum, 1883. Tiles had an average dimension of $25 \mathrm{~cm} \times 25 \mathrm{~cm}$.

29 Marius Panayotis Tano, the founder in 1870 of one of the oldest and most successful antiquities business in Cairo; Hagen and Ryholt, The Antiquities Trade, 266. 


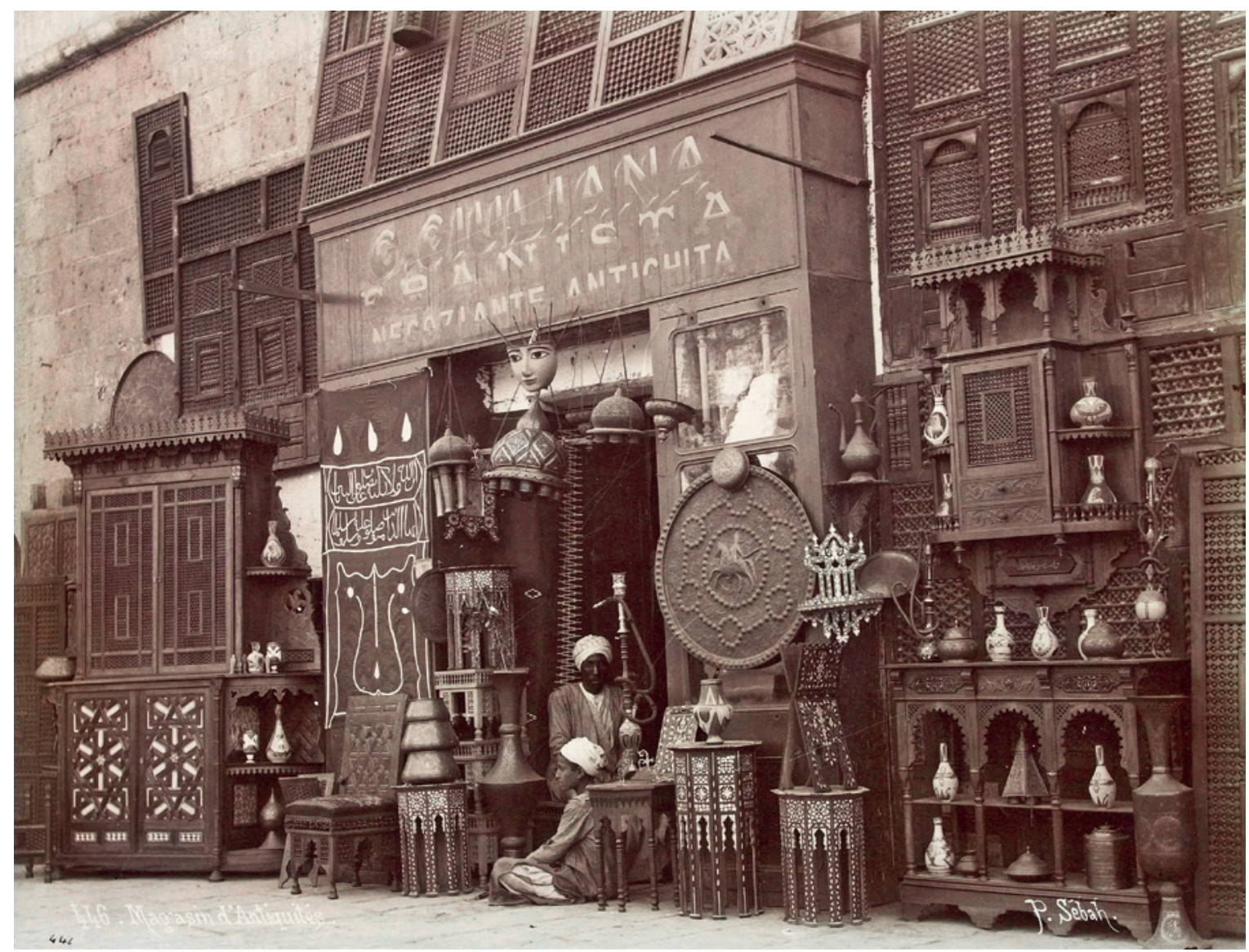

FIGURE 42 Pascal Sebah, Magasin d'antiquités, undated [c. 1881]. [The shop of antique dealer and cabinet-maker Gaspare Giuliana in Cairo]. Albumen print. $19.69 \times 26.04 \mathrm{~cm}$

MINNEAPOLIS INSTITUTE OF ART, 82.57.71. GIFT OF CHARLES HERMAN

Kyticas, and two British intermediaries. The first was Reverend Greville Chester (1830-92), an Oxford alumnus and ordained clergyman, who used to trade antiques as a side activity, and the second the numismatist Edward Thomas Rogers Bey (1831-84), who was an early advocate of the preservation of Islamic monuments in Egypt. ${ }^{30}$ At the time, selling artefacts and supporting

30 Stanley Lane-Poole, "Arab art monuments," The Academy VI (1874), 354, 361; Warren R. Dawson and Eric P. Uphill, Who Was Who in Egyptology (London: The Egypt Exploration Society, 1995, 3rd edition), 361; Mercedes Volait, Fous du Caire, 183, 187. heritage preservation were not seen as contradictory; acquiring such objects was actually considered as a way to keep them from destruction. Of course, this did not always hold true, as we have just seen with the case of broken qamariyyāt. In any case, the range of people involved in the trade in Islamic antiques was obviously diverse. They could be dedicated dealers, but also cabinetmakers, a photographer, art lovers and occasional sellers. In this sense, it was still not an institutionalised trade. Remarkably, the deals primarily concerned salvage from old houses. To some collectors, architectural specimens were indeed far more collectable than decorative objects. 
1.2

\section{"Vastly More Important Than}

\section{Bric-à-Brac"}

The dual nature of Giuliana's business - dealing in antiques and producing Arab style furniture, also termed Arabesque - can best be explained by the culmination of a specific, and somewhat ephemeral, fashion that took Egypt by storm, just as it had gripped France previously: the reuse of historic fragments in new handicrafts. A by-product of the passion for antiques that had seized Europe at the end of the eighteenth century, the second life offered to antiques through their repurposing in modern fittings was to acquire the dimensions of an industry in France from the 188os. The technique came to be known as clunisienne in an explicit reference to the Musée de Cluny in Paris, a medieval mansion that had been refurbished and refurnished anew by the collector and archaeologist Alexandre Du Sommerard (1779-1842). He is credited as the inventor of a practice consisting of combining old fragments and new Revival parts to produce historicist pieces, that is to say modern fittings with an authentic old flavour. The procedure was particularly effective for furniture. It allowed for the creation of a new sofa out of an old armchair (by cutting it in two parts and inserting a new piece in the middle), or a cabinet out of loose panels. The (re)creation was not meant to be hidden; it was not, technically speaking, a forgery. This type of work strived to satisfy a demand for old items that was so vigorous that there were no longer sufficient originals to fulfil it. ${ }^{31}$

The technique clunisienne reached Egypt quite early on. As seen in Chapter 1, a number of items of composite nature mixing old and new material were presented by Egypt at the 1867 Universal Exposition in Paris. Among them was the display console designed for the Khedive, which included a large historic panel of wooden marquetry. (Fig 22 and 23, Chapter 1) The doors of the Khedivial pavilion were partially made of historic panels, such as

31 Manuel Charpy, "Le théâtre des objets, Espaces privés, culture matérielle et identité bourgeoise. Paris, 18301914" (PhD diss., Tours University, 2010), 536-38.
Ottoman roundels. The console and doors thus represent the earliest known examples of mixedperiod Islamic artefacts from Egypt in the nineteenth century, and it is telling that the Egyptian ruler had destined them for Paris, either as artistic model to follow or as evidence of on-going craftsmanship. A "restored ancient window" was presented by the cabinet-maker Giuseppe Parvis in the class of luxury furniture, along with windows with coloured glass and historic panels made of carved ivory. ${ }^{32}$ Among the items sent to Paris in 1867 by Husayn Fahmi, also mentioned in Chapter 1, was a "modern French table" with a top made of thirtyone carved panels from the pulpit of the Mosque of Altinbugha al-Maridani (fourteenth century). This piece of furniture was among the ones purchased by the South Kensington Museum in $1867-69 .{ }^{33}$ It is no longer possible to view it, as the table was deaccessioned in 1939 under the motive that it was largely "made up of modern ingredients," besides being "an unwieldy and cumbrous object," and hence "not suitable for exhibition."34 It was consequently sold on 6 June 1939 at Stevens auction rooms as no. 83 with the description of "a large circular top Moorish table, inlaid ivory on octagonal stand." ${ }^{35}$ Contrary to what is commonly assumed, entering a museum has not been a guarantee of eternal life for the artefact, and gone with this table were the precious Mamluk carved polygons. Tastes, space constraints and display strategies within museums not strictly tied to inalienable collections, as is generally the case in Great Britain apart from major institutions such as the British Museum, do shift overtime. Accidental losses also happen in inalienable collections. The work of keeping safe decontextualised art is demanding.

At a later international fair, the 1876 Centennial Exhibition in Philadelphia, another composite

\footnotetext{
32 Edmond, L'Égypte à l'Exposition universelle, 335.

33 London, Victoria and Albert Museum, 1049-1869.

34 London, Victoria and Albert Archive, MA/5o/2/35: Departmental Boards of Survey, Furniture and woodwork (1935-1939), Policy File.

35 London, Victoria and Albert Archive, MA/50/2/35 Stevens's auction rooms, Catalogue of sale no. 15547,5 .
} 
piece displayed among the Egyptian exhibits caused something of a sensation. The object was presented by Egypt's "National Museum" (i.e. the Museum of Egyptian Antiquities) in class no. $45^{2}$ devoted to inlaid work in wood and metal. ${ }^{36}$ It consisted of a minbar door reconstructed out of detached ivory carved polygons, re-mounted onto a modern board following a sixteen-branch star pattern. An inscription at the bottom of the door bore the name of Sultan al-Zahir Barquq (r. 1382-89 and 1390-99). Strikingly odd to the modern beholder, the work was considered a genuine fourteenthcentury piece and valued at the astonishing and extravagant price of $\$ 14,000 .{ }^{37}$ It was bought and donated to the Boston's newly-established Museum of Fine Arts by an amateur Egyptologist who was interested in providing American art students with examples of good design and delicate workmanship. ${ }^{38}$ Other (plainer) composite doors were proposed by Parvis in the class of "Heavy Furniture,"39 (Fig. 43) similar examples of which (doors and cabinets) can be viewed today in the new National Museum of Egyptian Civilisation that opened in Cairo in 2016; others are displayed in the Islamic gallery of the modest Archaeological Museum of Cairo University. They adorn many an interior; some have appeared in recent auctions. (Fig. 44 and 45) Although never studied per se, this Revival production, intermixed with historic

36 United States Centennial Commission, International Exhibition of 1876 Official Catalogue (Philadelphia: Centennial Catalogue Company, 1876), 236.

37 The Centennial Exhibition of 1876, What We Saw, How We Saw it, Part II, A Tour through the Main Building (Philadelphia: S.T. Souder \& Co, 1876), 36.

38 Boston, Museum of Fine arts, 77.1; Laura Weinstein et al., Ink, silk \& gold: Islamic art from the Museum of Fine Arts (Boston: MFA Publications, 2015), 49.

39 United States Centennial Commission, International Exhibition of 1876, 236-37. On Parvis's Mamluk style furniture, Mercedes Volait, "Goût de la réplique et art de la reprise: le mobilier 'de style arabesque' au Caire après 186o," in D'une rive à l'autre: patrimoines croisés, eds. Sylvia Naef, Pauline Nerfin and Nadia Radwan (Genève: Slatkine, 2018), 223-34. material, was not inconsiderable. It deserves proper research.

As we shall see (Chapter 4 ), the principle of integrating historic components into modern design was extended from furniture to architecture by French expatriates residing in Cairo in the 1870s. Among them was architect Ambroise Baudry whose specialty became architectural reuse. He designed several houses, including his own, along the formula of recycling Islamic salvage for surface decoration. A mention in his correspondence evidences that as early as 1872 , a stock of old mashrabiyas and cupboards was being purchased for the house he was designing in Cairo for Baron Alphonse Delort de Gléon (1843-99), another recent French resident in Egypt and an early collector of Islamic art. ${ }^{40}$

While strongly impacted by the Cluny model and vogue, the reuse of Islamic salvage was by no means an exclusively French phenomenon. In his recollections of purchases made in the Middle East, the American collector and designer Lockwood de Forest (1850-1932), who was to make a living out of reviving Indian woodcarving for interior decoration and furniture in the United States, wrote:

When I was in Cairo and Damascus in 1876 and again in 1882, I had bought such things to preserve them where ever I could. I considered the architectural specimens of buildings and interiors vastly more important for our Museums than the bric-à-brac usually collected and called objects of fine arts. Such things as house fronts balconies doors paneling [sic] of walls and cuttings are very bulky and require space to store them. For years I have been collecting such things as I thought the Metropolitan Museum should have. I had filled my own houses full and in some cases loaned to different museums. I had tied up

Private collection, Letter of Eugène Picard to Ambroise Baudry, Cairo, 20 January 1871 [sic for 1872]. 


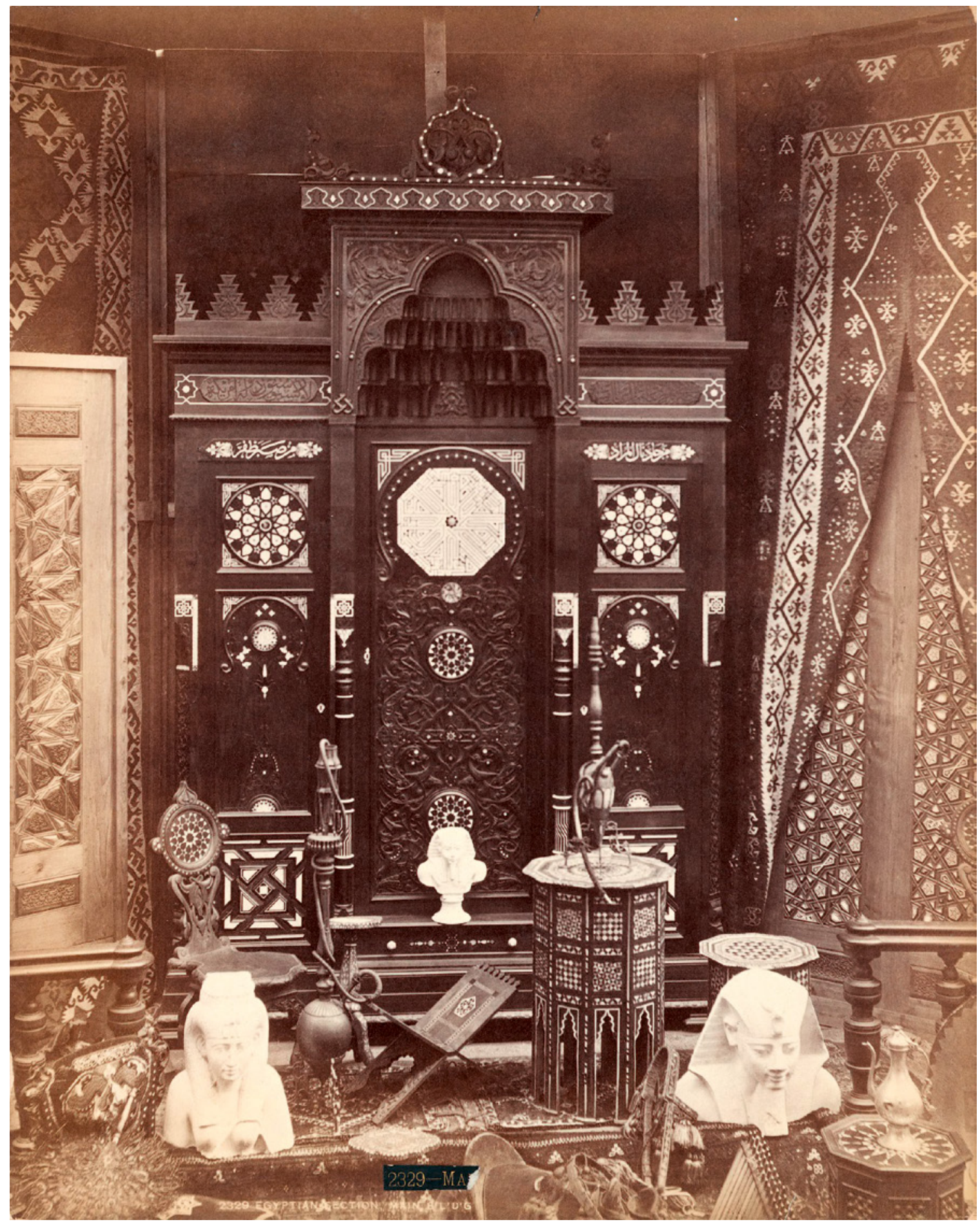

FIGURE 43 Centennial Photographic Company, Egyptian section in main building. [Exhibits by Giuseppe Parvis at the Egyptian section of the 1876 Centennial Exhibition in Philadelphia]. Silver albumen print. $26 \times 21 \mathrm{~cm}$ FREE LIBRARY OF PHILADELPHIA, PARKWAY CENTRAL LIBRARY, PRINT AND PICTURE COLLECTION, C022329 


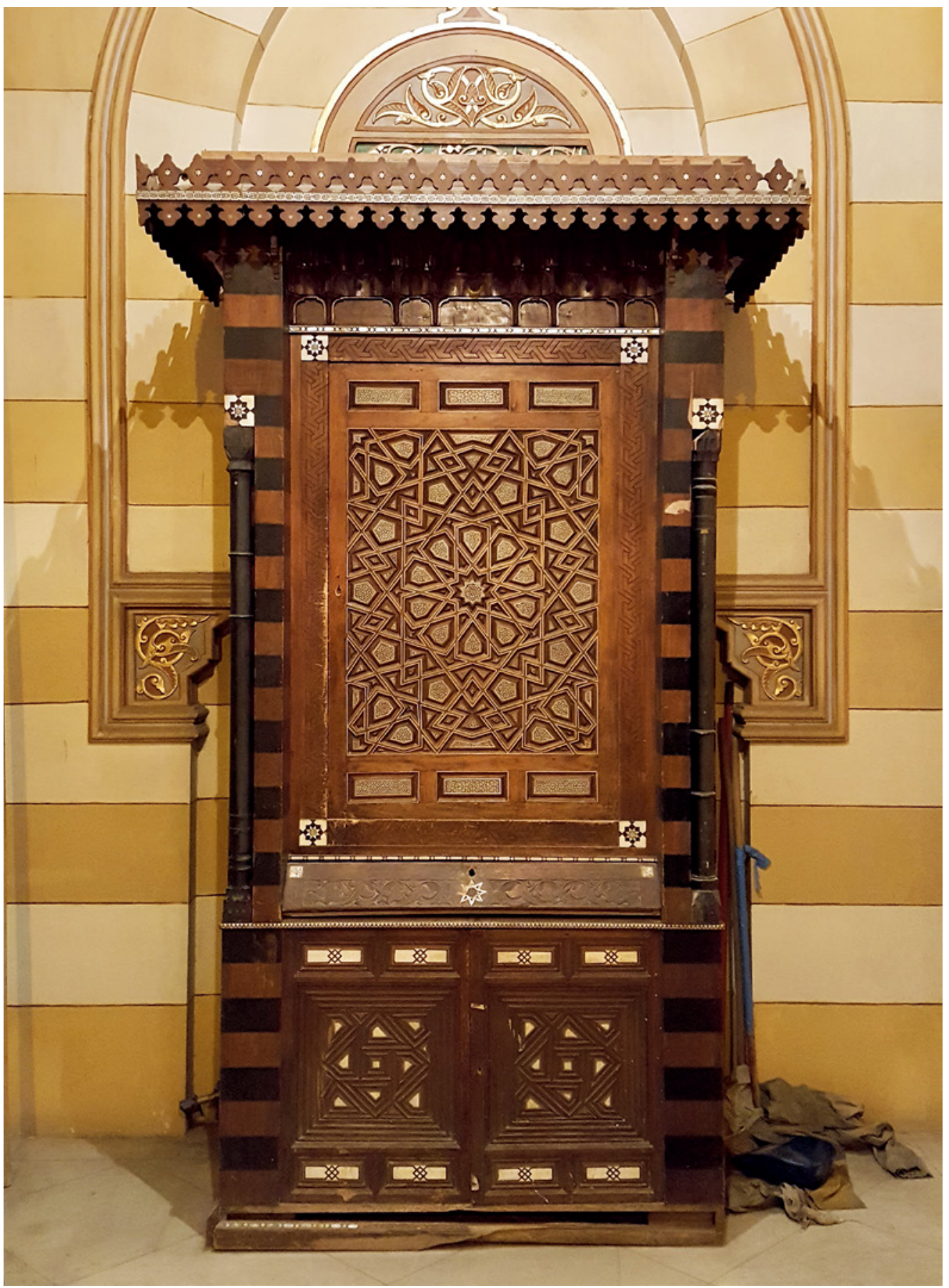

FIGURE 44 Cupboard with historic panels, possibly made by the Jacovelli brothers, third half of the nineteenth century, standing in a Cairene building PHOTOGRAPH BY THE AUTHOR, 2017 


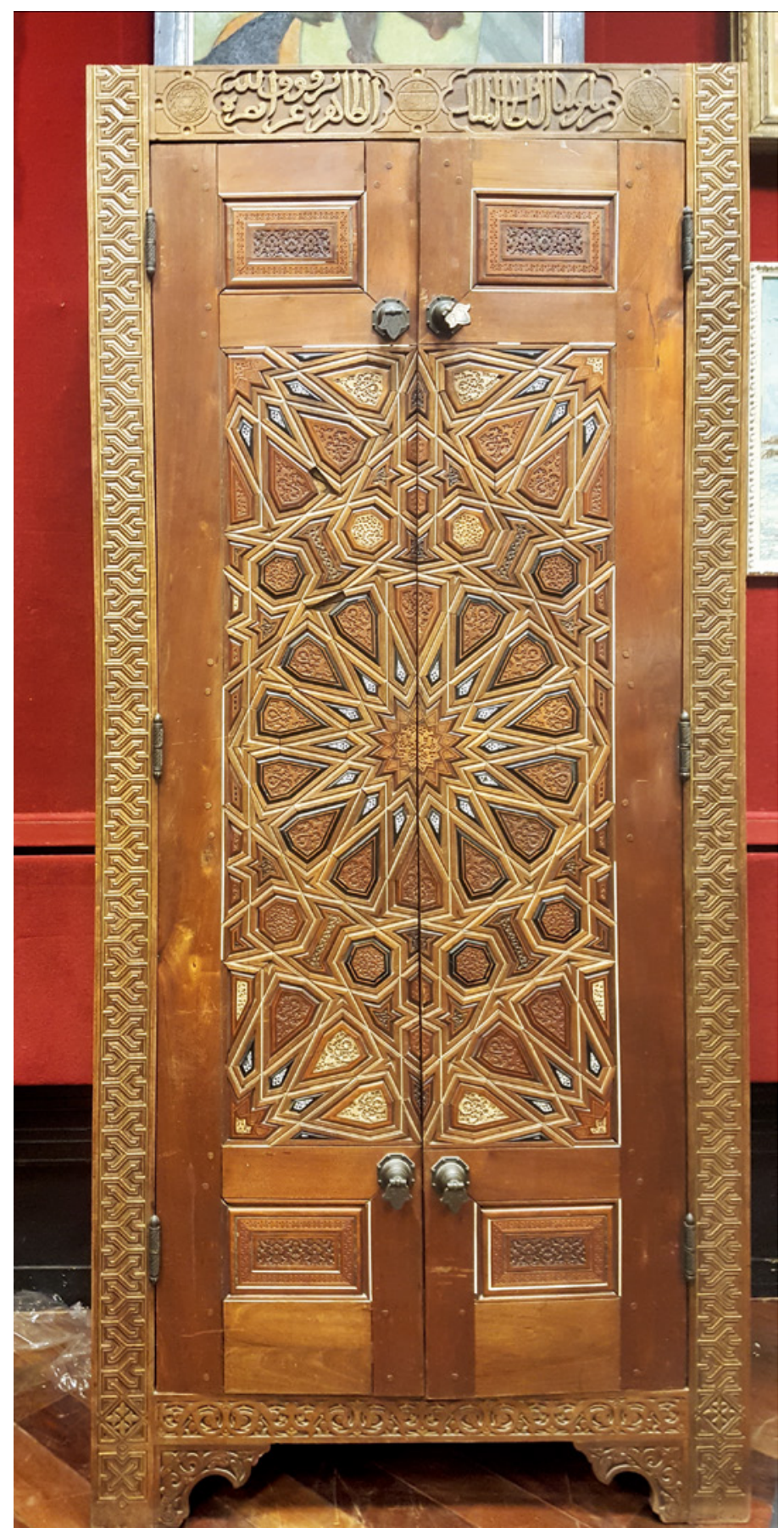

FIGURE 45 Mamluk style cupboard from the collection of Ernest de Blignières, made in Cairo c. 1880. Auctioned by Ader Nordmann on 23 May 2017 (lot 296) in Paris, hammer price

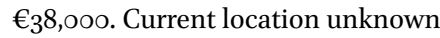
PHOTOGRAPH BY THE AUTHOR, 2017 
quite a large amount of my money in such things. ${ }^{41}$

He too repurposed what he bought and brought back home in the interiors he designed, including his own apartment and showroom in New York, on 9 East 17th Street, where several walls were fully tiled with Damascene specimens. ${ }^{42}$ (Fig. 46 and 47).

In short, before Islamic antiques became, in the 189os, an established trade with recommended dealers and identifiable shops in the bazaars, diverse types of transactions, made by people with renowned flair, had already taken place. It could consist of merchandise being offered at home to exclusive collectors or opportunities to purchase salvage from willing providers. For connoisseurs, the institutionalisation of the market actually signalled the end of fruitful procurements. On 4 December 1881, the scholar Arthur Rhoné (1836-1910) reported to Byzantinist Gustave Schlumberger (1844-1929) that the “[Cairo's] bazaars were empty: not a single tile left, not one old piece of brass available." ${ }^{33}$ According to Baudry, who had become an expert buyer, the market was furthermore highly volatile, with daily fluctuations and unpredictable supply:

41 Washington, Smithsonian Institution, Archives of American Art, Lockwood de Forest papers, 1858-1980, Box 1, folder 63, Handwritten draft of Indian Domestic Architecture, circa 1919, Part 4, view 75 (foliated 286). Roberta A. Mayer, Lockwood de Forest: Furnishing the Gilded Age with a Passion for India (Newark: University of Delaware Press), 2008; Damascene tiles from the Lockwood de Forest collection can be viewed at the website of dealer Anthony Slayter-Ralph [https:// anthonyslayter-ralph.com/islamic-tiles/index2.html], accessed on 13 March 2021.

43 Paris, Institut de France, Correspondance Schlumberger, Ms 4250, Letter no. 14: "Les bazars sont vides: plus une seule faïence, un seul cuivre ancien. En ce genre aussi on verra de grandes choses; dans dix ans, on ne verra plus rien!"
Le bazar est essentiellement journalier, un jour tout abonde dans le sens qu'on désire, tout s'écoule et des années se passent avant que la veine se rouvre. Actuellement le bazar en est réduit aux rebuts de Constantinople, aux faux poignards ou haches d'armes de Tiflis, aux faux cuivres de Damas, aux chandeliers découpés à jour et autres horreurs dont je me détourne avec mépris. ${ }^{44}$

Visual depictions of typical bad imitations being offered to European tourists at Cairo bazaars nicely complement Baudry's observation. (Fig. 48) The scene painted by Nicola Forcella (1868-1911) captures with humour a group of tourists, looking very out of place, and encouraged on by their dragoman, on the verge of buying over-priced merchandise. Depicting artefacts for sale became a favourite topic of the Orientalist genre of painting. The Austrian artist Ludwig Deutsch (18551935) particularly delighted in the theme during the 189 os. $^{45}$

In 1875 , the best rugs were already to be had in Paris, as Lockwood de Forest discovered when he visited AuBon Marché, the newly-built department store that had opened on Rue de Sèvres in 1872 . He had never seen "so many in one place," and most were "perfect beauties." 46 The store had been sell-

44 Cairo, Scientific archives of Institut français d'archéologie orientale, Fonds Rhoné, no. 34, Letter of Ambroise Baudry to Arthur Rhoné, 19 January 1885: "The bazaar operates on a daily basis. One day, there could be an abundance of what one is looking for, and then years could pass before the flow begins once more. Nowadays, the bazaar is mostly limited to leftovers from Constantinople, sham daggers from Tiflis, fake brass from Damascus, cut-out brass candlesticks and other horrors that I discard with contempt." [My translation].

45 Many are now in the collection of Egyptian businessman Shafik Gabr and illustrated in Parry, Orientalist Lives.

46 Washington, Smithsonian Institution, Archives of American Art, Lockwood de Forest papers, 1858-1980, Box 2, Folder 28, Travel Journal for Europe and the Middle East, $1875^{-76}$, Entry for 20 November 1875 . 


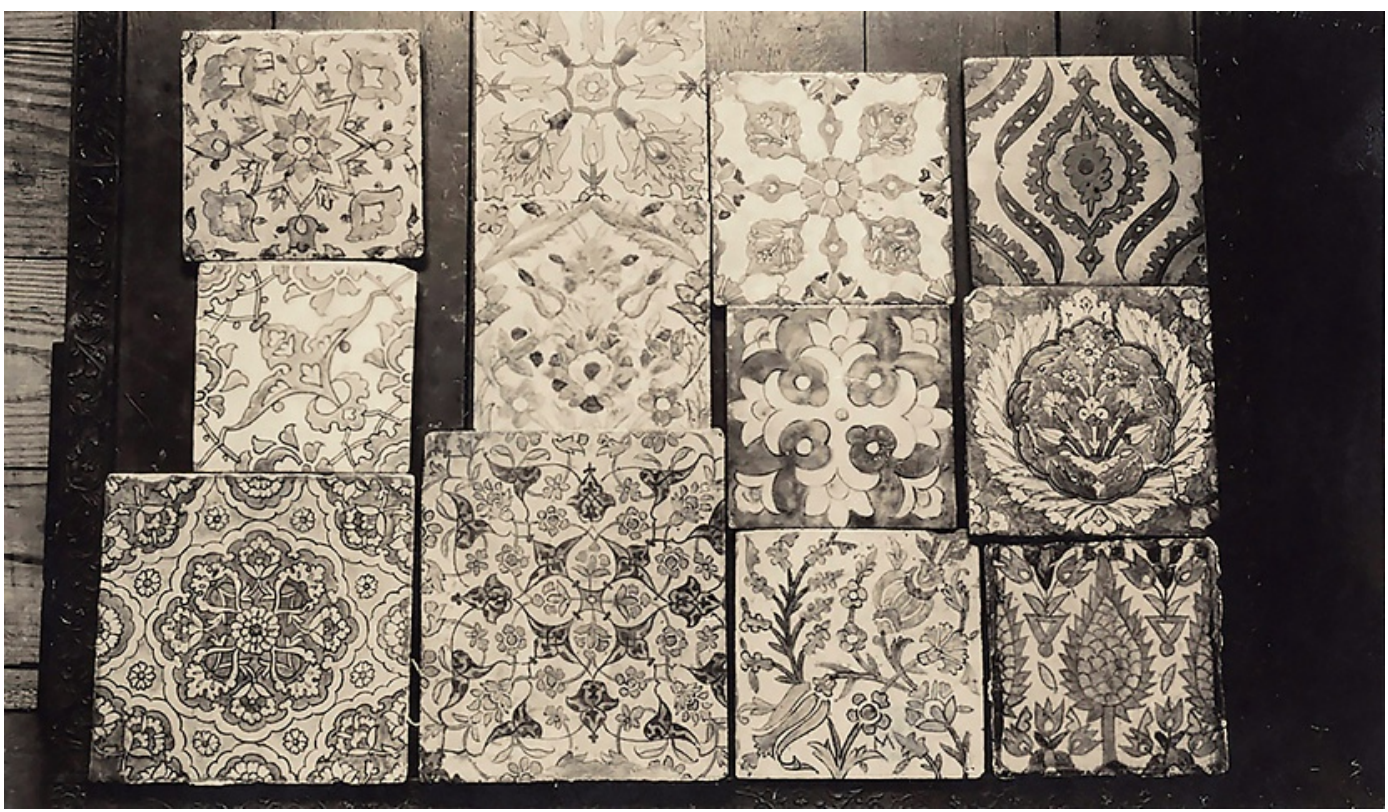

FIGURE 46 Damascene tiles from the Lockwood de Forest collection, brought to the US in 1876 or 1882 . Albumen print. No dimensions provided WASHINGTON, DC, ARCHIVES OF AMERICAN ART, LOCKWOOD DE FOREST PAPERS, 1858-1980, BOX 3, FOLDER 35, F. 6

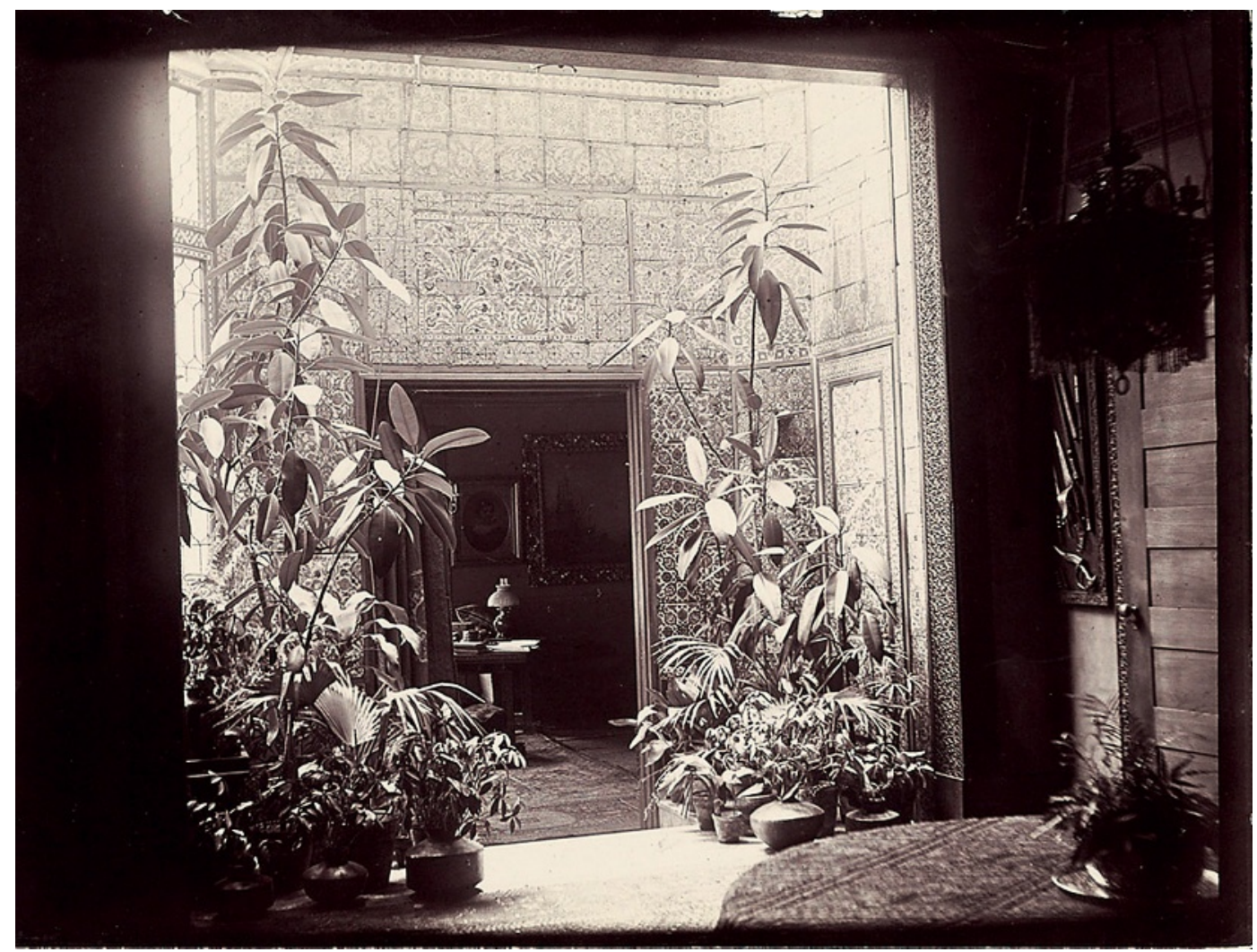

FIGURE 47 A tiled corner with Damascene specimens at Lockwood de Forest's house, 9 East 17th Street, New York, designed in 1887. Albumen print. No dimensions provided WASHINGTON, DC, ARCHIVES OF AMERICAN ART, LOCKWOOD DE FOREST PAPERS, 1858-1980, 


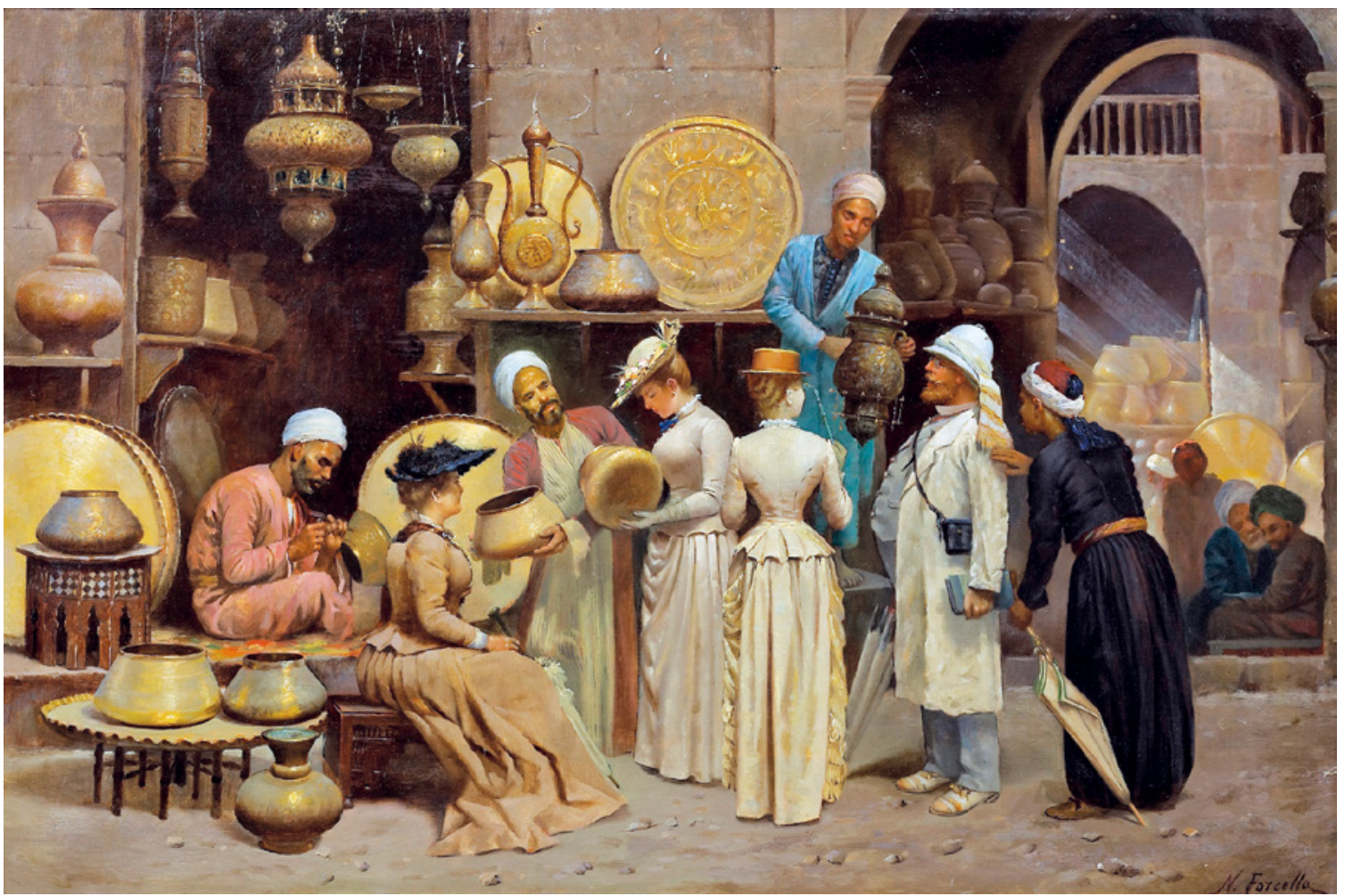

FIGURE 48 Nicola Forcella, Dans le souk aux cuivres, undated (c. 189o). [Tourists at the Coppersmiths' bazaar in Cairo]. Oil on canvas. $48 \times 72.5 \mathrm{~cm}$ AUCTIONED AT SOTHEBY'S PARIS ORIENTALIST SALE, 24 OCTOBER 2007, LOT 26. CURRENT LOCATION UNKNOWN

ing Oriental rugs almost since its opening. ${ }^{47}$ It had agents sent on annual tours to Turkey (Smyrna in particular), Egypt, Armenia and Iran to buy and ship stock to Paris. (Fig. 49) The store boasted special galleries for "Tapis d'Orient" and organised major sales every fall. ${ }^{48} \mathrm{~A}$ rival store, Les Magasins du Louvre, had a fine selection as well. Well-established carpet dealers in Cairo were soon to market their best pieces directly to these giant retailers, as Baudry observed in 1885 about a

47 Michael B. Miller, The Bon Marché: Bourgeois Culture and the Department Store, 1869-1920 (Princeton, N.J.: Princeton University Press, 1981), 50; 168-74.

48 Au Bon Marché, Grande exposition et mise en vente des tapis de l'Inde, de la Perse, de la Turquie, du Maroc et de la Syrie (catalogue) (Paris: Boucicaut et fils, 1876). merchant named Abdallah in the Khan al-Khalili. ${ }^{49}$ Known as the most successful carpet dealer in the bazaar at the time, this man is most probably the one featuring in the series "Le Caire pittoresque: photographies d'après nature” published by photographers Carlo Naya and Otto Schoefft after $1874^{50}$ (Fig. $5^{\circ}$ ) This is a further example which

49 Cairo, Archives scientifiques de l'Institut français d'archéologie orientale, Fonds Rhoné, no. 34, Letter of Ambroise Baudry to Arthur Rhoné, 19 January 1885: "Ce vieux coquin d'Abdallah lui-même ne fait plus rien qu'avec les grands magasins de Paris;" Arthur Rhoné, L'Égypte à petites journées, Le Caire d'autrefois (Paris: Henri Jouve, 1910), 268.

50 The print kept at the Met is a close variant of the view no. 44 included by Carlo Naya and Otto Schoefft in their series “Le Caire pittoresque;" see Felix Thürlemann, Das Haremsfenster: zur fotografischen Eroberung Ägyptens im 19. Jahrhundert (Paderborn: Wilhelm Fink, 2016), 63; 


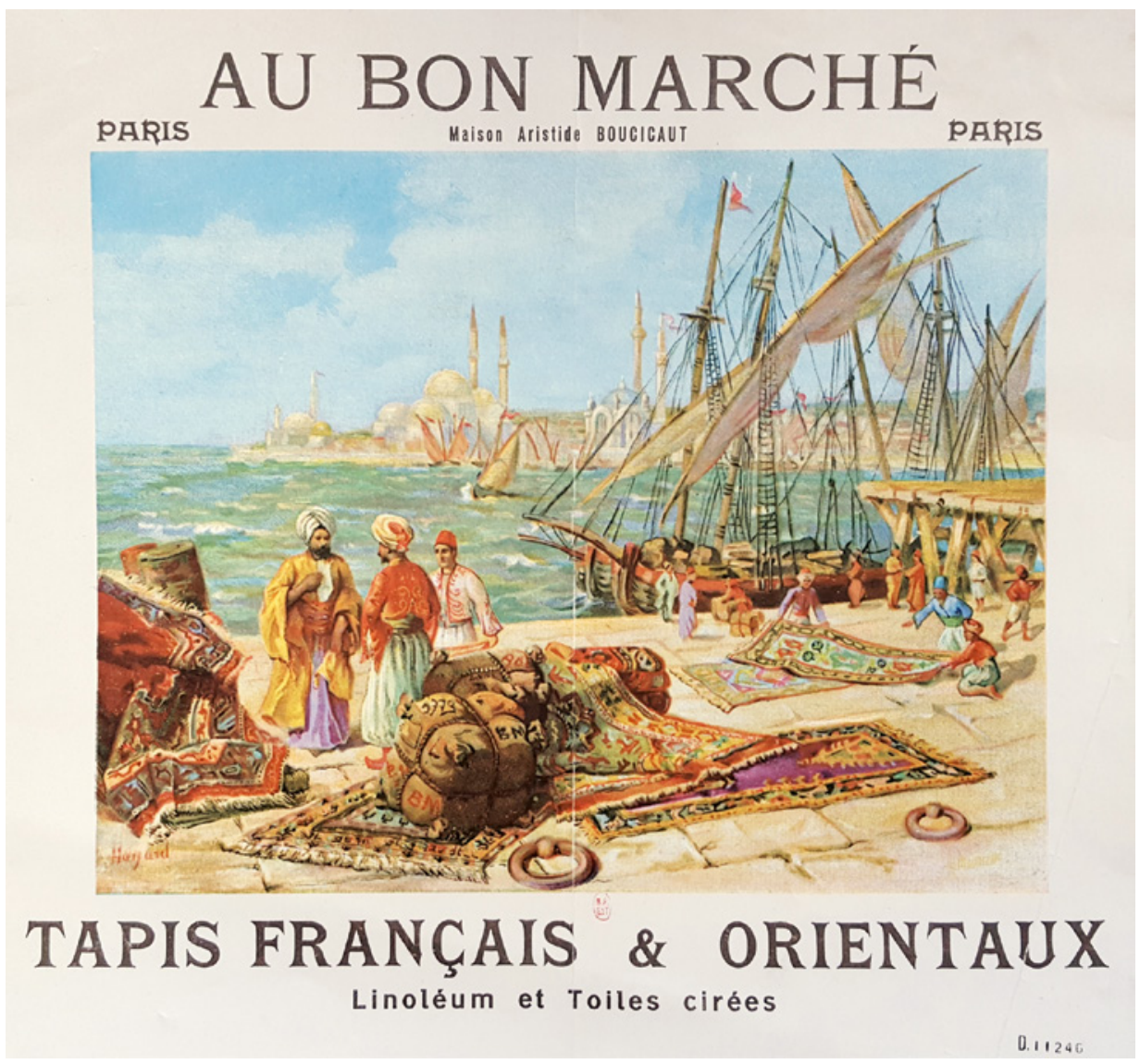

FIGURE 49 Au Bon Marché, Tapis francais et orientaux, c. 1878. Chromolithograph PARIS, BIBLIOTHÈQUE NATIONALE DE FRANCE, ESTAMPES ET PHOTOGRAPHIE, D 11246

demonstrates that, by the mid-187os, the golden age of Cairo's bazaars for antique hunting had well and truly passed.

\subsection{From Abū Antīqa ...}

The commercial life of historic artefacts in Damascus follows a different pattern, or at the very least prompted a distinct narrative. Mentions of authentic antique dealing in the city appear much earlier than in Cairo. The earliest occurrence identified so far is in a traveller's account written by French banker and historian, Baron Fernand de Schickler (1835-1909). A whole chapter

Paris, Bnf, Estampes et photographie, oeuvre de Naya and Schoefft, EO-25O (1).
(Chapter $\mathrm{x}$ ) records a visit to the bazaars made on 9 November $185^{8.51}$ The tour ends by introducing readers to a famous character nicknamed "Père des antiquités" [Father of Antiques] by European travellers. The sobriquet is a literal translation of the expression $a b \bar{u}$ antīqa, meaning in colloquial Arabic literally "father of antiques," but figuratively used to qualify someone who knows about antiques and possesses such goods. It should be emphasised that this is the use of an Arabicised version of the Latin antica, instead of the classical Arabic athar, to designate historic vestiges and artefacts. Schickler reports most vividly on the

$51 \quad$ Fernand Schickler, En Orient; souvenirs de voyage, 1858 1861 (Paris: Michel Levy, 1863), 107-18. 


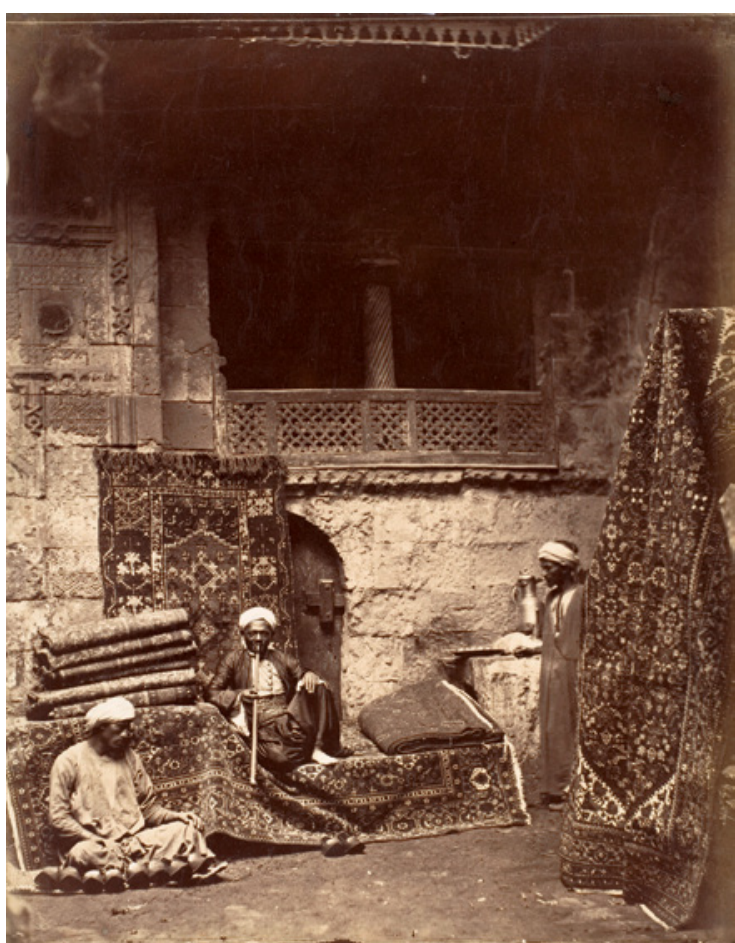

FIGURE 50 Carlo Naya and Otto Schoefft, Marchand de tapis [The merchant Abdallah at the carpet bazaar in Cairo], after 1874 . Albumen print. $28.2 \times 22 \mathrm{~cm}$ NEW YORK, METROPOLITAN MUSEUM OF ART, 2000.179 A, B

ways the dealer operated. ${ }^{52}$ He would come daily at lunch time to the guesthouse where all foreigners in town then lodged, an inn installed in an old house that was managed by a Greek former dragoman named Dimitri Kara. ${ }^{53}$ Seated at the end of the table, Abu Antiqa would display choice pieces: jewellery, a dagger, an intaglio stone, an engraved tray. Eventually, privileged customers would be taken to his house, adjoining the hotel. In a room opening onto the courtyard, objects sat on simple wooden shelves. Deals were made in a separate room (the typical ìwān of Damascene houses,

\section{Schickler, En Orient, 112-5.}

53 Initially based in Beirut, where he had already managed a hotel, Kara had moved to Damascus in 1856 see James Lewis Farley, Two Years in Syria (London: Saunders and Otley, 1858), 282. overlooking the courtyard?), to where objects were only brought one by one. Endless bargaining, with expressive pantomime, would take place for a few selected pieces. Only at the end of the visit, when the purchase was concluded, could Schickler wander more freely across the multiple rooms of the house which were packed with things, "from splendid old Chinese wares to Persian rugs." ${ }^{4}$

Under the alternate spellings of Abú Antiká, ${ }^{55}$ Abu Antica, ${ }^{56}$ Abou-Antica, ${ }^{57}$ Abou Antiqua, ${ }^{58}$ or Abou Antik, ${ }^{59}$ the man features in numerous accounts recording visits dated 1858 to 1871 ; all concur on his strong personality and astute commercial ways. According to Schickler, his first name was Abd-el-Kader, as the famous Algerian emir exiled in Damascus since 1855 was named. ${ }^{60}$ This was in fact about the sole Arabic name that was familiar to French people at the time; unsurprisingly, the dealer appears in another account under the name of Abdallah. ${ }^{61}$ Schickler recalled

54 Schickler, En Orient, 114.

55 Isabel Burton, The Inner life of Syria, Palestine, and the Holy Land: from my Private Journal (London: Henry S. King \& Co, 1875), I: 86.

56 Karl F. Werner, Hof im Hause des Scheich Bender, vulgo Abu Antica in Damaskus [The court of the house of Shaykh Bender, a.k.a Abu Antica, in Damascus], watercolour exhibited in 1866 in Leipzig.

57 Marcos Antonio De Macedo, Pèlerinage aux Lieux Saints, suivi d'une excursion dans la Basse Egypte, en Syrie et à Constantinople (Paris: Librairie internationale, 1867), 364; Vicomte de Savigny de Moncorps, Journal d'un voyage en Orient 1869-1870. Égypte-Syrie-Constantinople (Paris: Hachette, 1873), 172; John Dibblee Crace, Letters from Egypt and Syria, I: fol. 281 (London, Victoria and Albert archive, AAD/2001/6/328).

58 Jean-Louis Andral et al., eds., Album de voyage: Des artistes en expédition au pays du Levant (Paris: Rmn/ Afaa, 1993), 181.

59 Damas et le Liban: extraits du journal d'un voyage en Syrie au printemps de 1860 (par le comte de Paris), (Londres: W. Jeffs, 1861), 8, 11-12, 5o.

6o Schickler, En Orient, 112.

61 Damas et le Liban, 8. No match to either a relevant "Abd al-Qādir" or "Abdallah" can be identified in the Damascene prosopography worked out in Linda Schatkowski Schilcher, Families in Politics: Damascene Factions and Estates of the 18th and 19th Centuries (Stuttgart: Franz Steiner, 1985). 
an aged "Turkish merchant" wearing a white turban and impeccable robe; he might have been born around 1800 or even before. Beside his business in antiques, he was allegedly tasked with the control of the souks.

Isabel Burton, the wife of diplomat and Orientalist Richard Burton (1821-9o), who lived in Damascus in 1870-71, devoted an even longer chapter to dealings with Abu Antiqa. It is twelve years later, and the merchant, also referred to as "Shaykh Bandar," is now a "venerable white-bearded" man, "with an eye full of cunning, the manners of a gentleman," but occasionally bad-tempered and rather tough in business. ${ }^{62}$ Artists were fascinated with the sight of his bric-à-brac. The Dutch artist Wilhem de Famars Testas mentioned spending two mornings sketching the courtyard of the house of "Abou Antiqua," on 4 and 6 May 1868;63 two years earlier, the German water-colourist Karl Werner had exhibited in Leipzig his own view of the house Hof im Hause des Scheich Bender, vulgo Abu Antica in Damaskus. ${ }^{64}$ One visitor admitted that purchases at Abu Antiqa were mostly a pretext to have a look at objects piled up in barely lit rooms, a mesmerising sight. ${ }^{65}$ In any case, the venerable dealer was a popular figure.

In two references at least, the title of "Shaykh/ Sheikh Bandar" is associated with his name, while Schickler speaks of Abu Antiqa as a "marchand turc préposé à la surveillance du grand bazar" [a Turkish merchant in charge of the surveillance of the grand bazaar]. Both mentions, however, are erroneous and misleading. "Shaykh/Sheikh Bandar" is in fact an old misspelling for shah bandar, in full shah bandar al-tujjar, a term of Persian origin used for the head of the merchants' guilds, or "prévôt des marchands" in French sources. ${ }^{66}$ These guilds were independent from the muhtasib,

\footnotetext{
62 Burton, The Inner life of Syria, I, 86.

63 Andral et al., Album de voyage, 181.

64 Attempts to locate the work have proven unsuccessful so far.

65 Damas et le Liban, 12.

66 "Schëych Bendar" in Jean de Thévenot, Suite du "Voyage de Levant" (Paris C. Angot, 1674), 67.
}

the supervisor of the bazaars. The function of shah bandar was generally performed by merchants of considerable wealth and influence, traditionally engaged in the trade with the Hijaz in spices, coffee, and luxury goods. ${ }^{67}$

That a shah bandar - if he had actually been one? -, or any merchant for that matter, would shift to antiques is a clear sign of commercial reconfiguration. As a matter of fact, Damascus had been brought into the orbit of European commerce as early as the 182 os. The nine-year Egyptian rule over Syria starting in 1831 accelerated the trend. In 1840, about 120 large merchant houses, primarily Muslim, but also Christian and Jewish, specialised in European trade. The markets were dominated by British goods, which were retailed by a hundred shopkeepers. ${ }^{68}$ By the 185 os the penetration of European goods had provoked a severe crisis of the local economy, culminating in sectarian violence in 186o. Goods from abroad proved cheaper and more appealing. Damascene manufacturers soon lost their luxury markets to European imports; a number of crafts declined and ultimately disappeared. The steamship and the Suez Canal had also both badly affected pilgrimage traffic. Alternate trade routes and manufacturing lines were subsequently figured out. Expanding into commerce with Damascus' hinterland represented one strategy; devising new lines of production was another. ${ }^{69}$ Antique dealing might have been a way, however trivial, to adjust to the new situation. It had the double advantage of gifting a second life to commodities that had fallen out of fashion locally, while accommodating the European unquenchable thirst for Middle

67 Raymond, Artisans et commerçants, II, 580.

68 Abdul-Karim Rafeq, "A fractured society: Ottoman Damascus in the mid-19th century," in Histoire, archéologies, et littératures du monde musulman: Mélanges en l'honneur d'André Raymond, eds. Ghislaine Alleaume, Sylvie Denoix, and Michel Tuchscherer (Cairo: Publications de l'Institut français d'archéologie orientale, 2009), 193-204 (196-97).

69 Donald Quataert, "Ottoman handicrafts and industry in the age of European industrial hegemony, 18001914," Review 11, no. 2 (1988): 169-78. 
Eastern curios. Another related response was the production of "Oriental goods" for European and North American markets, which nevertheless also became goods for local consumption. ${ }^{70}$

\section{$1.4 \quad$... To the Damascene Antikji}

That antique selling became a thriving business in Damascus is confirmed by the recorded existence of a specific craft established under the name of antikji in the Arabic "Encyclopaedia on Damascene crafts" [Qamus al-sina'āt alshamiyya], drafted from 1891 to 1905 by three learned Syrian gentlemen. ${ }^{71}$ (There is no such equivalent profession known for Cairo). The noun is constructed from a derivation of the (Latin) word antica coupled with the Arabicised version of the Turkish occupational suffix $-j \bar{\imath}$ - indicating a trade or profession. Again, it is a good illustration of the expanding hybrid lexicon juggling with lingua franca, Turkish and Arabic at the time. The text explains that the antikji is someone that sells antiques [antīka], "by which is meant àthār qadīm" [literally, ancient traces]. The authors of the Qāmūs attribute the flourishing of the new trade to the eagerness of the al-Franj [literally Franks, i.e. Europeans] to buy very old wares, "especially the ones going back to distant times and generations, and with historic associations."72 They list among the desired valuables old textiles, rugs, tiles, brass vessels, wool and arms. Moreover, they connect the

70 James A. Reilly, "From Workshops to Sweatshops: Damascus Textiles and the World-Economy in the Last Ottoman Century," Review 16, no. 2 (Spring 1993): 199-213.

71 The work was published much later: Muhammad Sāìd al-Qāsimī, Kaalīl al-'Aẓm, Muḥammad b. Muhammad al-Qāsimī, Zā̄ir Qāsimī, Qamus al-sina'at al-shamiyya [Dictionary of Damascene crafts] (Paris: Mouton, 1960).

72 Muhammad al-Qāsimī et al., Qamus, 40-1. The entry is partially translated in Charles Issawi, The Fertile Crescent, 1800-1914: A Documentary Economic History (New York and Oxford: Oxford University Press, 1988), 388; also Marcus Milwright, "An Arabic description of the activities of antique dealers in late ottoman Damascus," Palestine Exploration Quarterly 143, no. 1 (2011): 8-18. development of the antique market to the growing numbers of tourists that were attracted to Baalbek and Palmyra, among other archaeological sites. They chart the chain of intermediaries by taking the example of an old copper bowl from Mecca, bought for a rupee or half riyal, resold to a Beirut antikji for thirteen gold francs (instead of the twenty francs initially asked for), who in turn sold it to a "Frankish tourist" for more than ten times that price (150 gold francs). They add that "many people grew wealthy, especially during the pilgrimage season in Jerusalem when many visitors come from Europe." Furthermore, they observe that the shops dealing in antiques also sold "imitations of old things" [taqlìd al-qadim], as well as "products of current handicrafts [al-ashghäl al-jadìda] with beautiful design and forms, and all are eagerly sought after by Franks." Some merchants "have made it a trade, and have appointed an agent abroad to whom they send merchandise."73

This was precisely the case of the Habra brothers, who appear in the purchase records of the Victoria and Albert Museum from 1894 to $1927 .{ }^{74}$ According to their letterhead on an invoice dated 1894, the firm was established in 1836 . The Habra brothers belonged to a Greek-Catholic family from Damascus; ${ }^{75}$ they carried out their business "in Eastern art treasures" from London, at least from the 188os, working through the humorous telegraphic address of "Kuskus, London." They presented themselves as both "manufacturers and direct importers of Oriental Works of Art" and could provide goods as different as "Turkish and Syrian embroideries, fancy furniture inlaid with mother of pearl, Benares ware, Moucharabia, Persian Brass trays, antique rugs," etc. They developed branches in Cairo and Damascus (where

\footnotetext{
73 Muhammad al-Qasimi et al., Qamus, 40-1.

74 London, Victoria and Albert Archive, Habra Brothers Nominal file, MA/1/ 116 .

75 One was named Cesar and went through a contentious divorce in Britain in 1914; "A Turk's Marriage at Damascus," The Times, Wednesday 25 February 1914 Issue 40456, p. 3 .
} 
their factories were located). ${ }^{76}$ Their dealings with the South Kensington Museum, however, mostly concerned salvage. They offered 135 Old Damascus tiles to the museum in 1894 for £1oo (bargained down to seventy-seven pounds sterling), and the following year an "antique Damascus fountain (damaged and repaired)" for seventy-two pounds sterling. ${ }^{77}$ Five years later, they managed to sell the museum eighteen panels of marble and semiprecious stone mosaics ("all more or less damaged"), that had been removed "to considerable expense" from an old house in Damascus, for the negotiated price of seventy-fixe pounds sterling. ${ }^{78}$ One suspects that Revival furniture may have been a far more successful branch of their trade. It proved the case for a similar firm, albeit better known: the one operated by the connected families of Tarazi (also spelled Tarrazi) and Terzis.

\section{The kursī as Global Commodity}

Originating from Edessa (present-day Turkey), the Tarazis allegedly had settled in Damascus in the early 18 oos. As their surname suggests (Tarazi), the family's skills were initially in tailoring, although their name is spelled in a slightly different way than the Arabic word identifying a tailor $[$ tarzī $] .{ }^{79}$ Part of the family relocated to Beirut after the 186o massacres, while another fled to Athens where it took the name of Terzis, a Hellenised version of Tarazi. Their investment in "Oriental goods" in Beirut came shortly afterwards. In 1862, Dimitri Tarazi opened a shop named Au Musée oriental,

76 London, Victoria and Albert Archive, Nominal files, MA/1/H16, Letter to Mr Skinner, dated 12 January 1905.

77 London, Victoria and Albert Archive Nominal files, MA/1/H16, Report on objects received from Habra brothers, 29 October 1894.

78 London, Victoria and Albert Archive Nominal files, MA/1/H16, Report on 17 Pieces of mosaic (all more or less damaged), bought from Habra Brothers, 7 April 1899. 773 to $783-1899$.

79 Camille Tarazi, Vitrine de l'Orient. Maison Tarazi, fondée à Beyrouth en 1862 (Beirut: Editions de la Revue Phénicienne, 2015). while his brother André Terzis established $A u$ Magasin oriental when back from Athens in 1868. Both shops marketed similar commodities, i.e. an assortment of manufactured silks, embroideries, Oriental rugs, mashrabiyas and "artistic furniture of Oriental style," besides old Persian carpets, old embroideries, and antiques. ${ }^{80}$ In contrast from the Habras, the goods were not manufactured by the brothers themselves, but by another pair of brothers, Georges and Selim Nassan in Damascus. ${ }^{81}$ The factory of the latter was probably created at about the same time (early 1870s?), as the dates of Georges Nassan (1851-1916) suggest. ${ }^{82}$ It became renowned, under the name of Grande fabrique de meubles et objets orientaux [Large workshop for Oriental furniture and artefacts], for its works in tapestry, brass and furniture, exporting as far as Algiers in the $188 \mathrm{os}^{83}$ as well as Paris, London, Cairo (Fig. 51), Tunis and Istanbul. ${ }^{84}$ The Tarazis also expanded geographically at rapid pace. Dimitri Tarazi opened a store in Jerusalem in 1895, and four years later another one in Damascus, while his brother André developed in Jerusalem from 1904 onwards. Both opened branches in Cairo in 1909.

One successful example of Revival furniture that achieved global fame through the Tarazis and the like, was the occasional table known as kursī in Arabic. Edward William Lane describes the item in his Manners and Customs of Modern Egyptians as a decagonal stand meant to receive upon it a round tray [saniyya], the two pieces combined forming

8o Tarazi, Vitrine de l'Orient, 8.

81 Tarazi, Vitrine de l'Orient, 26.

82 Death announcement in L'Écho d'Alger, 1st November 1916, 3, stating that Georges Nassan was Catholic. According to Stefan Weber, the Nassans were Armenians; Weber, Damascus, II: 94.

83 Advertisement for the trade of "Dimitri et Simon Nassan, Objets d'Orient (Armes, nacre, soierie, broderies, Tapis et cuivreries)," Alger-Saison, 5 February 1884, n.p.

84 Wolf-Dieter Lemke, Représentations de l'Orient: imagerie populaire fin de siècle (Beirut: Dar en Nahar, 2004), 161. 


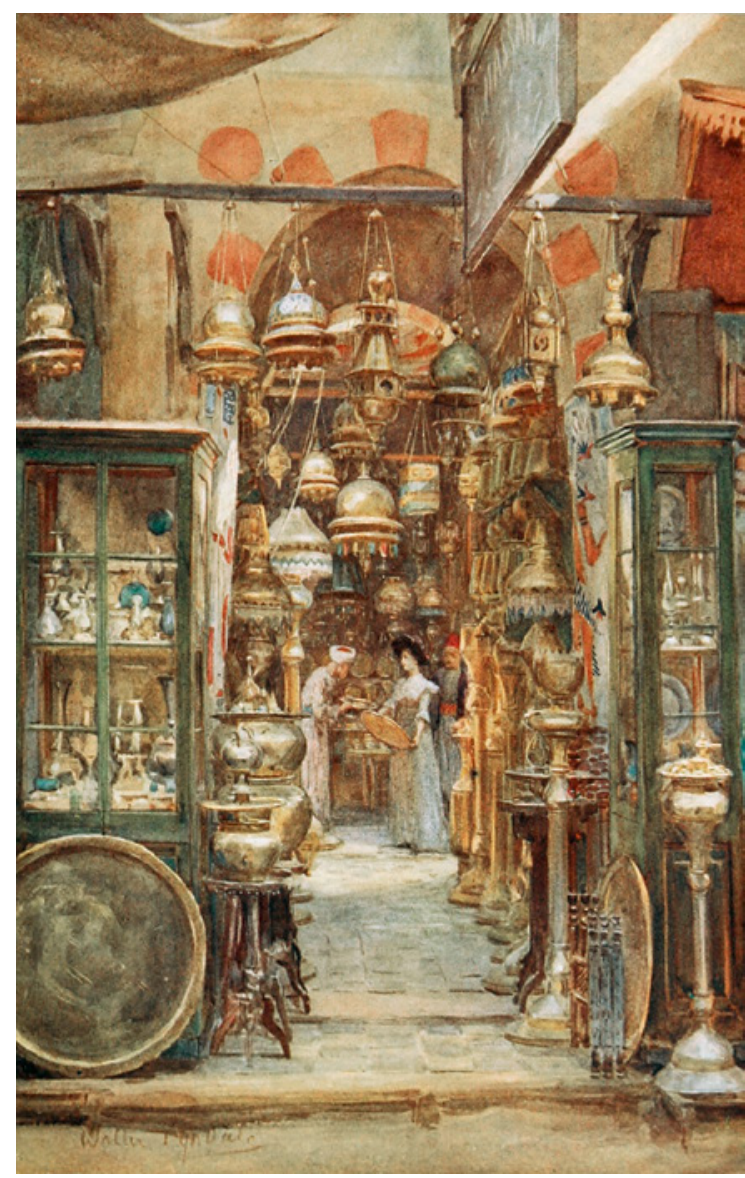

FIGURE 51 Walter Tyndale, The store of Nassan.

Chromolithograph

WALTER TYNDALE, AN ARTIST IN EGYPT 1912: FACING 136

the sufra or table where Cairenes ate. ${ }^{85}$ At the time of Lane's survey (1820-30s), the ordinary Egyptian kursi was fifteen inches high $(38 \mathrm{~cm})$, had ten legs and was inlaid with mother-of-pearl, tortoise-shell or bone, along a chess board marquetry pattern.

There is scant information on the history of this type of object, let alone its regional distribution. The earliest known kursi is attributed to the fourteenth century by the style of its carving; it was found in the Mosque of Umm al-Sultan Shaban,

85 Edward William Lane, Account of the Manners and Customs, 186o, 146-47. built in 1368 , in Cairo. ${ }^{86}$ However, it bears little resemblance to Lane's table. It is much higher and endowed with small openings fitted with turned wood. An early view of objects piled up in Cairo's Arab Museum (presently the Museum of Islamic Art) depicts several such furnishings besides the one salvaged from Umm al-Sultan Shacban Mosque (visible at the left of the image). (Fig. $5^{2}$ ) Their function is still unknown. They were long said to be furniture to house Qur'ans but their size makes them unfit for that purpose. ${ }^{87}$ On the other hand, tray stands did exist in the region well before the nineteenth century but they were made of metal, bore names of emirs and dignitaries, and were consequently exclusive objects, not a common part of domestic life. ${ }^{88}$ To add to the confusion, Islamic art historians also used the term kursi to refer to the large item of furniture in many Mamluk mosques in Cairo which combined a place to read the Qur'an over a cupboard for storing the holy book, a structure also known as a dikka. ${ }^{89}$ In contemporary Egyptian dialect, kursī means primarily a seat, and particularly a chair.

Wooden side tables, mostly decagonal and with geometrical patterns, can be spotted in the iconography of Cairene interiors produced all throughout the nineteenth century. Works by Émile Prisse d'Avennes (after a drawing by Ippolito Caffi dated

86 In the collection of the Museum of Islamic art in Cairo, but not on view; Lane-Poole, Art of the Saracens, 14344, fig. 66; Colonel F.S. Leslie, "The Turned Lattice Work of Egypt," Journal of the Society of Architects 4, no. 41 (March 1911): 167-77.

87 On their use as holders of objects or manuscripts, Sophie Makariou and Carine Juvin, "The Louvre kursi: Function and meaning of Mamluk stands," in Doris Behrens-Abouseif, ed., The Arts of the Mamluks in Egypt and Syria: Evolution and Impact (Goettingen: V\&R Unipress, 2012), 37-53. According to Doris Abuseif (personal communication, March 2019), they might have served as incense burners.

88 Ladan Akbarnia et al., The Islamic World: A History in Objects, 148.

89 Gaston Migeon, "The cover of a koursi," The Burlington Magazine for Connoisseurs 2, no. 6 (August 1903): 344, 347 . 


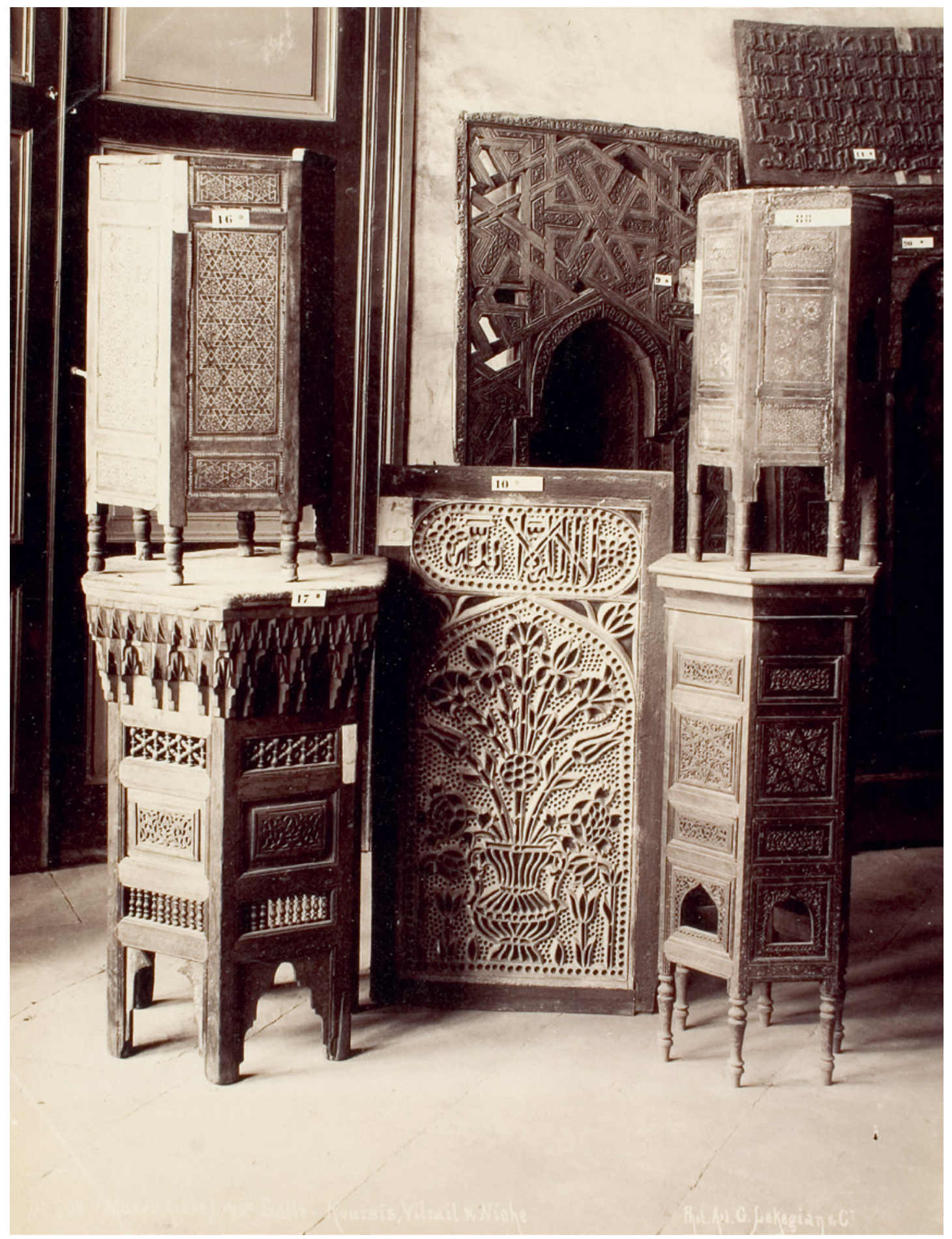

FIGURE 52 Garabed Lekejian \& Co., Musée arabe, 4ème salle, Koursis, vitrail et niche, c. 189o [Stands and other artworks in rooms built within the Mosque of al-Hakim, the first premises of Cairo's Arab Museum]. No dimensions provided

NANTES, BIBLIOTHÈQUE MUNICIPALE JACQUES DEMY, FONDS NORMAND, ÉGYPTE 2A, 508 
$1844^{90}$ - Fig. 53), David Roberts (engraving printed in 1855 under the title The Ghawazee of Cairo), or Frederick Goodall (watercolour dated 1875), ${ }^{91}$ are good examples. An early nineteenth-century kursī was donated to the Musée du Louvre in 1856; it had been in the private collection of French collector Charles Sauvageot (1781-186o), one of the men who inspired Balzac to create the character of Cousin Pons, exemplifying the type of art lover bereft of financial means who sacrifices everything to his mania. ${ }^{92}$ (Fig. 54) The side table greatly resembles Lane's stand and was most probably a contemporaneous object, if not one which was older by several decades. There is no equivalent visual evidence for the Syrian context. The word kursī appears in a few seventeenth-century probate inventories of Damascene denizens, but without a clear-cut definition of its function; the sufra then consisted of a piece of leather that was used on the floor and most interiors seem to have been devoid of any furniture, apart from chests to store apparel..$^{93}$ It can be inferred that, whatever its genealogy, Lane's kursī characterises an innovation, reflecting a change in manners and etiquette on matters of eating and drinking. Architectural historian Stefan Weber has similarly demonstrated that furniture or décor today deemed traditional

9o Mercedes Volait, "Émile Prisse d'Avennes au travail: un art de la collecte et de la compilation," in Émile Prisse d'Avennes: un artiste-antiquaire en Égypte au XIX $X^{e}$ siècle, ed. Mercedes Volait (Cairo: Publications of Institut français d'archéologie orientale, 2013), 75-102 (fig. 14, 16).

91 London, Victoria and Albert Museum, 517-1882, Copt Mother and Child, signed and dated 1875 .

92 Élise Anglade, Musée du Louvre, Catalogue des boiseries de la section islamique (Paris: Rmn, 1988), 16o; the kursī is OA934; André Lorant, Les Parents pauvres d'Honoré de Balzac, La Cousine Bette, le Cousin Pons (Geneva: Droz, 1967), 262-67.

93 Jean-Paul Pascual, "Meubles et objets domestiques quotidiens des intérieurs damascains du XVII ${ }^{\mathrm{e}}$ siècle," Revue du monde musulman et de la Méditerranée, no. 55-56, (1990): 197-207. in Damascene homes were in fact the legacy of late Ottoman modernity. ${ }^{94}$

The modern kursī acquired various names and shapes while transitioning into a global commodity. It appears indistinctly as a "Turkish stool," "Syrian coffee table," "Damascus stool," "Arabian table," "tabouret table" (from the French tabouret meaning a seat without back), or indeed "Damascus taborette," in a number of English printed sources. The Syrian version is characterised by floral patterns and sprays. A photograph of a tabouret seller in Damascus c. 1870 only displays models with this typical floral design. ${ }^{95}$ The specimen that came with the mid-eighteenth-century Damascus room acquired in 1875 by British architect Caspar Purdon Clarke also bears a design of floral nature and was considered at the time "ordinary nineteenth-century Syrian manufacture."96 So do most of the examples staged in a room at the German consulate in Damascus around 189o, probably in the context of a sale promoting local handicraft - an activity still current in diplomatic circles across the Middle East. (Fig. 55) It is very likely that geometric models - in addition to the version with lattice work - were a Cairene specialty, while the ones with vegetal pattern were produced in Damascus, but it is difficult to ascertain provenances in the absence of robust evidence. The available imagery reveals that, whether of the Cairo geometric type or the Damascus floral one, new models adopted many shapes, whether decagonal, octagonal or hexagonal.

94 Stefan Weber, Damascus: Ottoman Modernity and Urban Transformation (1808-1918), Proceedings of the Danish Institute in Damascus v (Denmark: Aarhus University Press, 2009), I: 304-07; 396-401.

95 Badr El-Hage, Des Photographes à Damas (1840-1918) (Paris: Marval, 200o), 145.

96 The room was subsequently sold to the South Kensington Museum in London; Moya Carey, "Appropriating Damascus Rooms: Vincent Robinson, Caspar Purdon Clarke and Commercial Strategy in Victorian London," in Francine Giese et al., eds., À l'orientale, $65^{-81}$. The side table is about 16 inches high, or $40 \mathrm{~cm}$ (Victoria and Albert Museum, 411q-188o). 


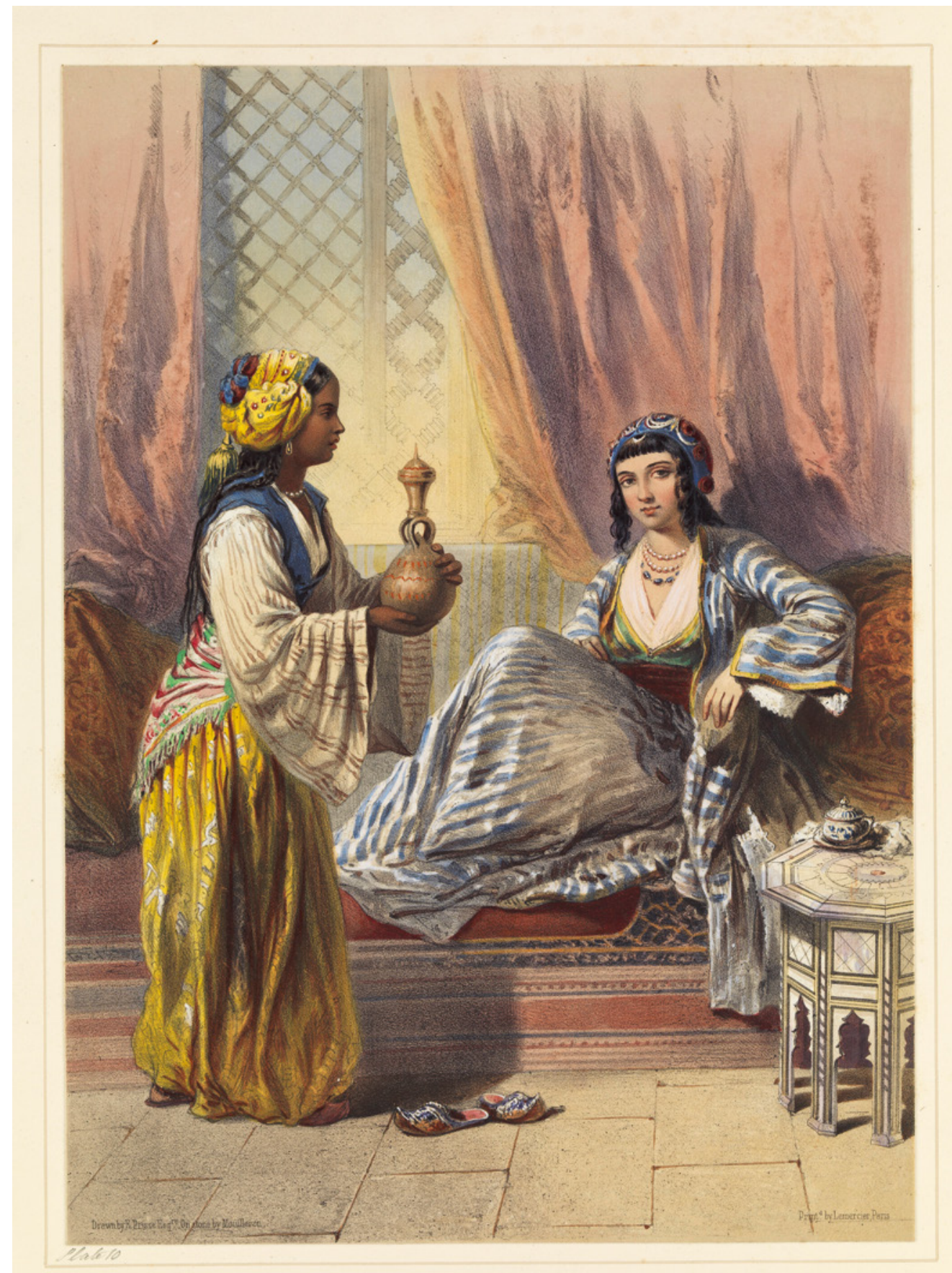

FIGURE 53 Émile Prisse d'Avennes, Cairene Lady Waited upon by a Galla slave. Chromolithograph after a watercolour by Ippolito Caffi, dated 1844

ORIENTAL ALBUM: CHARACTERS, COSTUMES, AND MODES OF LIFE, IN THE VALLEY OF THE NILE, 1848: PL. 10 


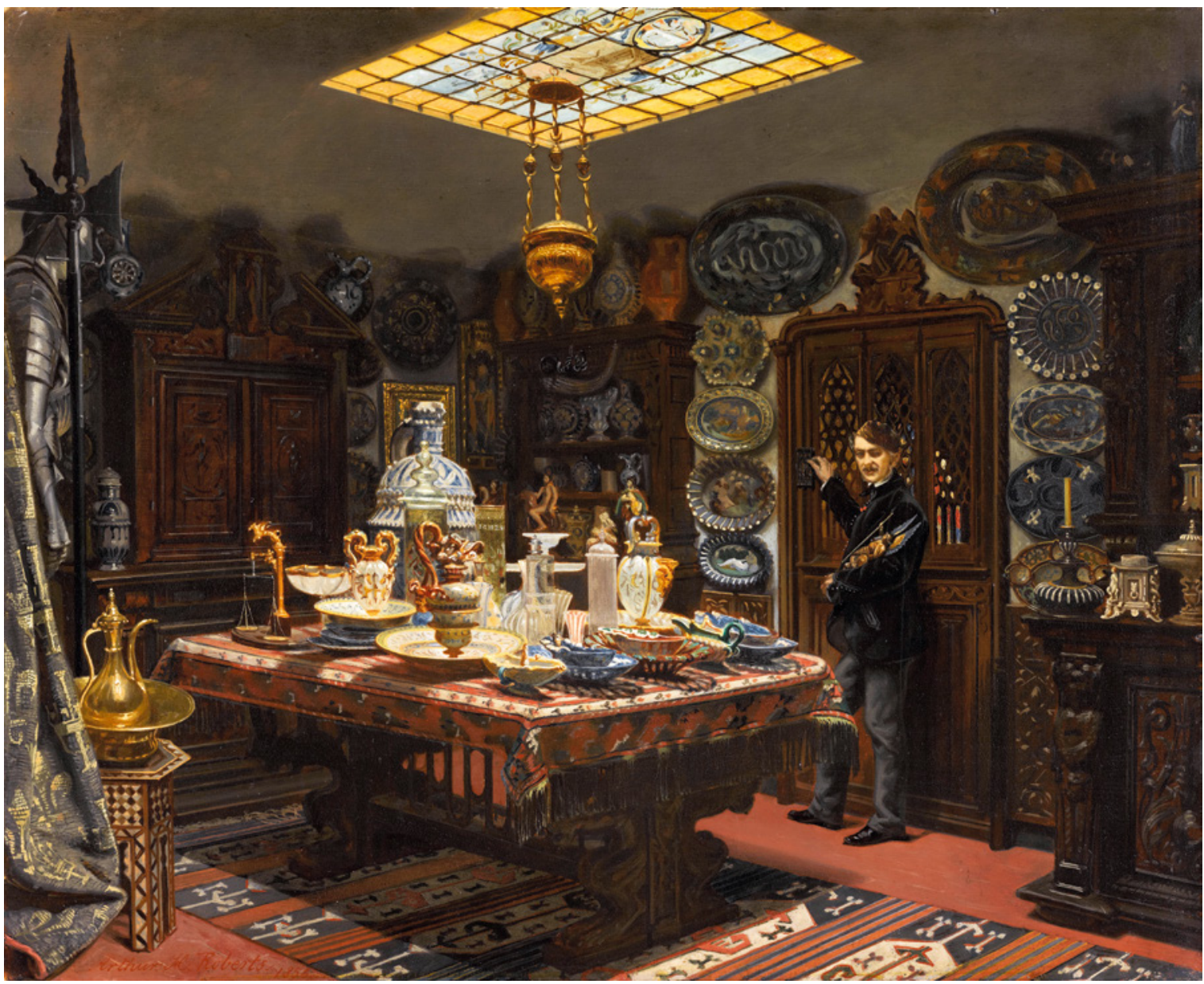

FIGURE 54 Arthur Henri Roberts, Vue intérieure d'une des pièces de l'appartement de monsieur Sauvageot. [A room at the flat of collector Charles Sauvageot]. The kursī stands on the left side of the image and is topped by a ewer. Oil on canvas. $48.5 \times 59 \mathrm{~cm}$ PARIS, MUSÉE DU LOUVRE, MI861 (CHARLES SAUVAGEOT' BEQUEST, 1856)

Western purchases provide further hints on the social life of the modern kursi. The Prussian Prince Herman von Pückler-Muskau had an octagonal stand and matching casket fully inlaid with mother-of-pearl made expressly for him in Egypt during his Near Eastern tour, with the presumable purpose of making his journey more comfortable and enjoyable, in 1834-40.97 Artists delighted in the portable device. The American Frederic Edwin

97 Illustrated in Parkomanie: die Gartenlandschaften des Fürsten Pückler in Muskau, Babelsberg und Branitz, exhibition curated by Agnieszka Lulinska (Bonn, Munich: Prestel, 2016), 278, fig. 232-234.
Church (1826-1900) brought back at least one "Arabian table" from his stay in the Syrian capital in 1868, and bought a few more in New York in the following decades. ${ }^{98}$ Frank Dillon (1823-1909), the British water-colourist, had several in the Eastern style studio he had arranged in London following repeated Egyptian sojourns in the 185os,

98 Hudson (US), Olana New York State Historic Site, inv. OL.1981.69o and oL.1979. 26; Karen Zukowski, Historic Furnishings Report for Olana State Historic Site: A History of the Interiors, Thoughts on Their Significance, and Recommendations for Their Restoration (Hudson, NY: Olana New York State Historic Site, 2001). 


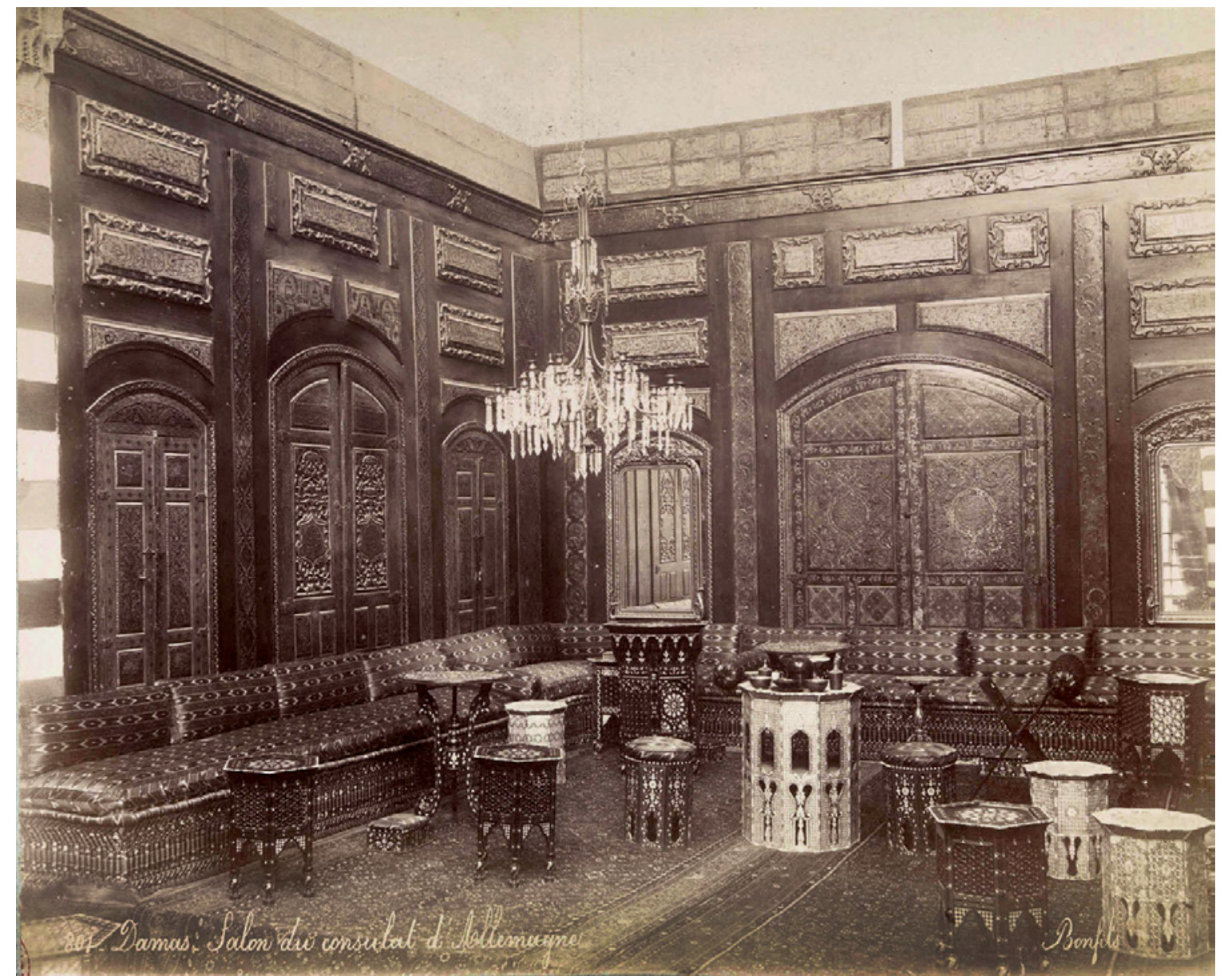

FIGURE 55 Félix Bonfils, Salon du consulat d'Allemagne, c. 189o. [Staged karāsī (pl. of kursī) in a room at the German consulate in Damascus]. Albumen print. $23 \times 28.2 \mathrm{~cm}$

CHARENTON-LE-PONT, MÉDIATHÈQUE DE L'ARCHITECTURE ET DU PATRIMOINE, APMFO011799

186os and 1870 os. ${ }^{99}$ In 1884, fellow Parisian painters Benjamin-Constant, Emmanuel de Dieudonné, Émile Foubert and Gustave Courtois all had tabouret tables in their studios, mostly of the geometric type. ${ }^{100}$ French artist Henri Matisse purchased in 1918 a "guéridon arabe" that he used as prop in some compositions. ${ }^{101}$ (Fig. $5^{6}$ )

99 Illustrated in Georg Ebers, Egypt: Descriptive, Historical, and Picturesque (London, Paris \& New York: Cassell, Petter Galpin \& Co, 1885), II: $85^{-6}$.

100 Pierre Wat, ed., Portraits d'ateliers. Un album de photographies fin de siècle (Grenoble: Ellug/INHA/MsH Alpes, 2013), 25, 37, 83, 143 .

101 Nice, Musée Matisse, 63.2.131 (former collection of Henri Matisse); Matisse in the Studio, eds. Ellen
By the late 1870 , the distinctly and easily recognisable Middle Eastern side table could be obtained anywhere. Inaugurated in London in 1875, the department store Liberty and Co had several models in various heights advertised in its first catalogue titled Eastern Art Manufactures and Decorative Objects [1881]. All were supplied

McBreen and Helen Burnham (Boston: Museum of Fine Arts, 2017), 118. While given as "likely of Tunisian origin," the decagonal stool (15.5 inches high or about $40 \mathrm{~cm}$ ) that Matisse acquired definitely in April 1918 from a Parisian dealer closely resembles the Egyptian archetype and can be dated to the early 1800 . 


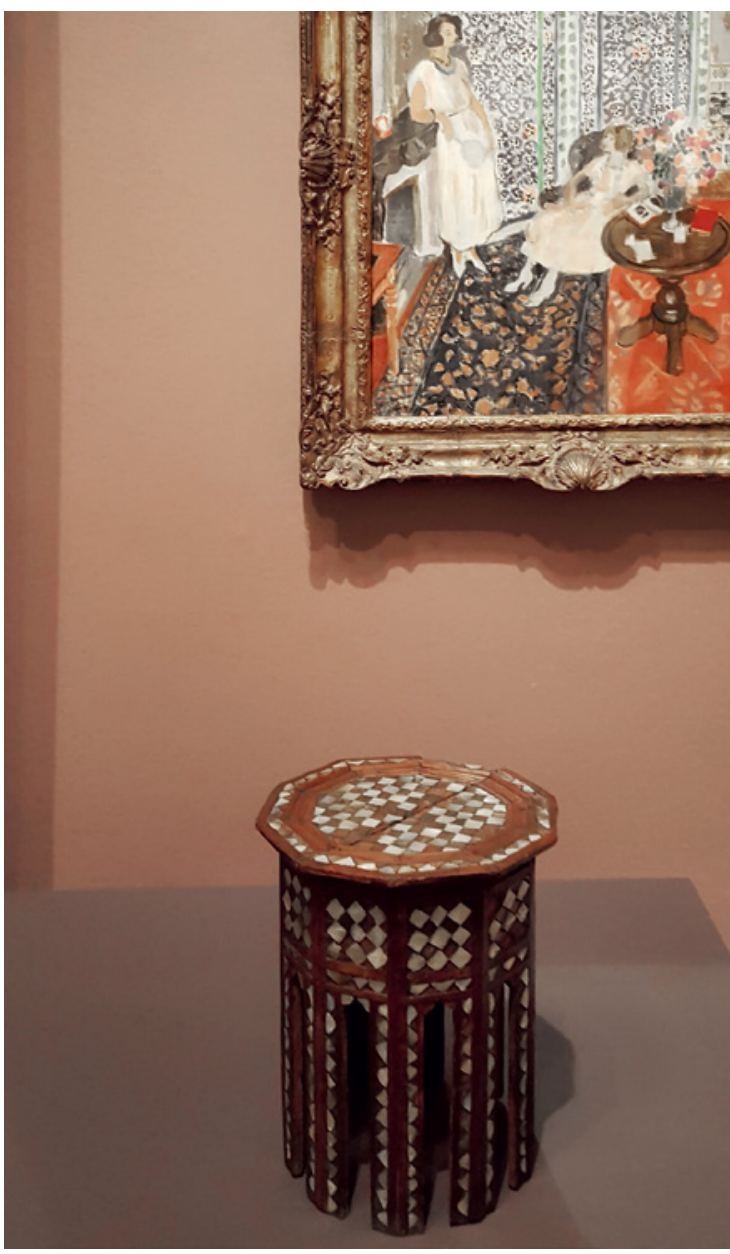

FIGURE 56 Matisse's guéridon arabe at the Royal Academy in London in 2017

PHOTOGRAPH BY THE AUTHOR, 2017

by Middle Eastern manufacturers. ${ }^{102}$ (Fig. 57) "Noticing the growing appreciation of Cairene goods," another British firm, Rottmann, Strome and Co., while specialised largely in Japonaiserie, opened a department of "Moorish furniture" from Cairo in the 188 os, serviced by a "first class maker of furniture" in the Egyptian capital. ${ }^{103}$ In both cases, Parvis' Cairene workshop, founded in 1859, was certainly a major provider; his

102 Daryl Bennett, Liberty's Furniture 1875-1915, The Birth of Modern Interior Design (Suffolk: The Antique collectors' club, 2012), 31, 62 .

"Oriental art in St. Mary axe," The Cabinet maker and Art furnisher, 1st February 1886, 213-14. showroom (Fig. 58) displayed models very close to the ones marketed by Liberty and Co or Rottmann \& Strome. By 1878 , Parvis is known to have been employing no less than fifty workers (one third of them Europeans and the other two thirds local staff). ${ }^{104}$ (Fig. 59) The figure had doubled in $1900,{ }^{105}$ and the Italian cabinet-maker was now competing with many other manufacturers, such as the Furino brothers and Giuseppe and Nicola Jacovelli, besides Gaspare Giuliana, Paul Philip and others, already mentioned above. Parvis' production was moreover distributed by the Tarazis in Beirut, Damascus and Jerusalem. ${ }^{106}$ Whatever the history of the modern kursī, the specifics of its crossbreeding between Cairo and Damascus, and the details of its regional outreach, it had become a global fixture by 1900 . Its portability contributed much to its wide distribution, as did its evocative quality.

Tourists to the Holy Land no longer needed to dive into the complexities of bargaining at the souks to get their "tabouret table;" they had a selection of available models on offer at the very premises of their hotel in Damascus, as a photograph taken by Bonfils in 1893 evidences. ${ }^{107}$ Meanwhile, the inlaid Damascene table had become a musthave in the US; shoppers were encouraged by the magazine Vogue in 1899 to get "inlaid Damascus taborettes" as "they were $\$ 10$ " and "much smarter than the usual taborette."108 Biscuit tins were designed after its shape around 1900, and this

104 Europeans probably include here Italian, French, Maltese and Greek carpenters, while the two other thirds were defined as "Arabs" in the source - but as well known, these categories could be rather porous; Gustave Delchevalerie, "L’Égypte agricole, industrielle et artistique," 365-452 (434).

105 Paola Ricco, "Art and luxury in the details: Italian interior decorators in modern Egypt, 1859-1967," in Building beyond the Mediterranean: studying the archives of European businesses (1860-1970), eds. Claudine Piaton et al. (Arles: Honoré Clair, 2012), 157-67.

106 Tarazi, Vitrine de l'Orient, 27.

107 Bonfils, Intérieur de l'hôtel Victoria à Damas, 1893 Albumen print on card, Fuad Debbas collection, EAP 644/1/62. 2 February 1899, 76 . 


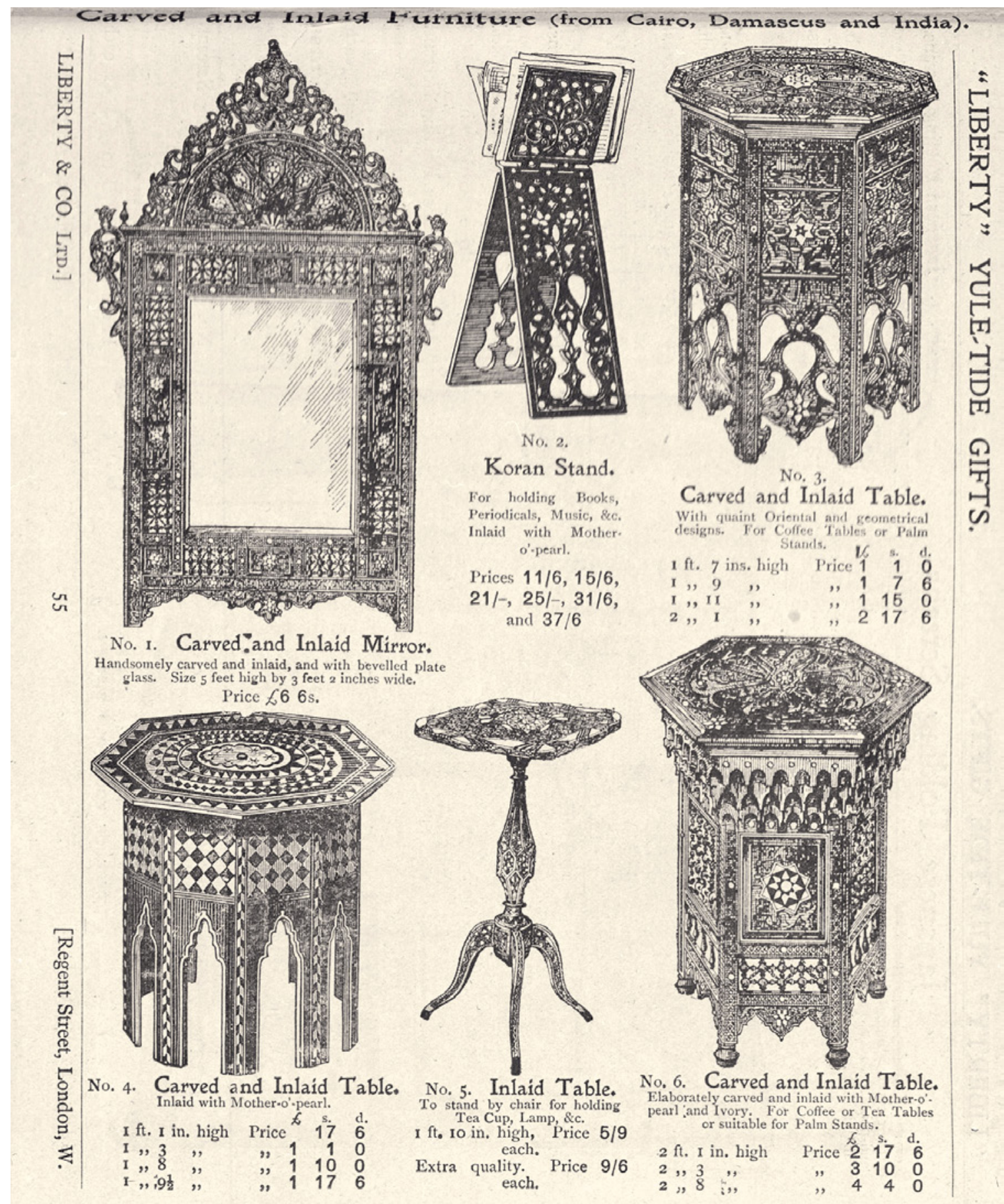

FIGURE 57 Carved and inlaid furniture (from Cairo, Damascus and India) on sale at Liberty's \& Co in London in 1895-96 YULE-TIDE GIFTS: CATALOGUE CONTAINING 274 ILLUSTRATIONS OF EXCLUSIVE AND INEXPENSIVE NOVELTIES, SUITABLE FOR DAINTY PRESENTS, 1895-96: 55 


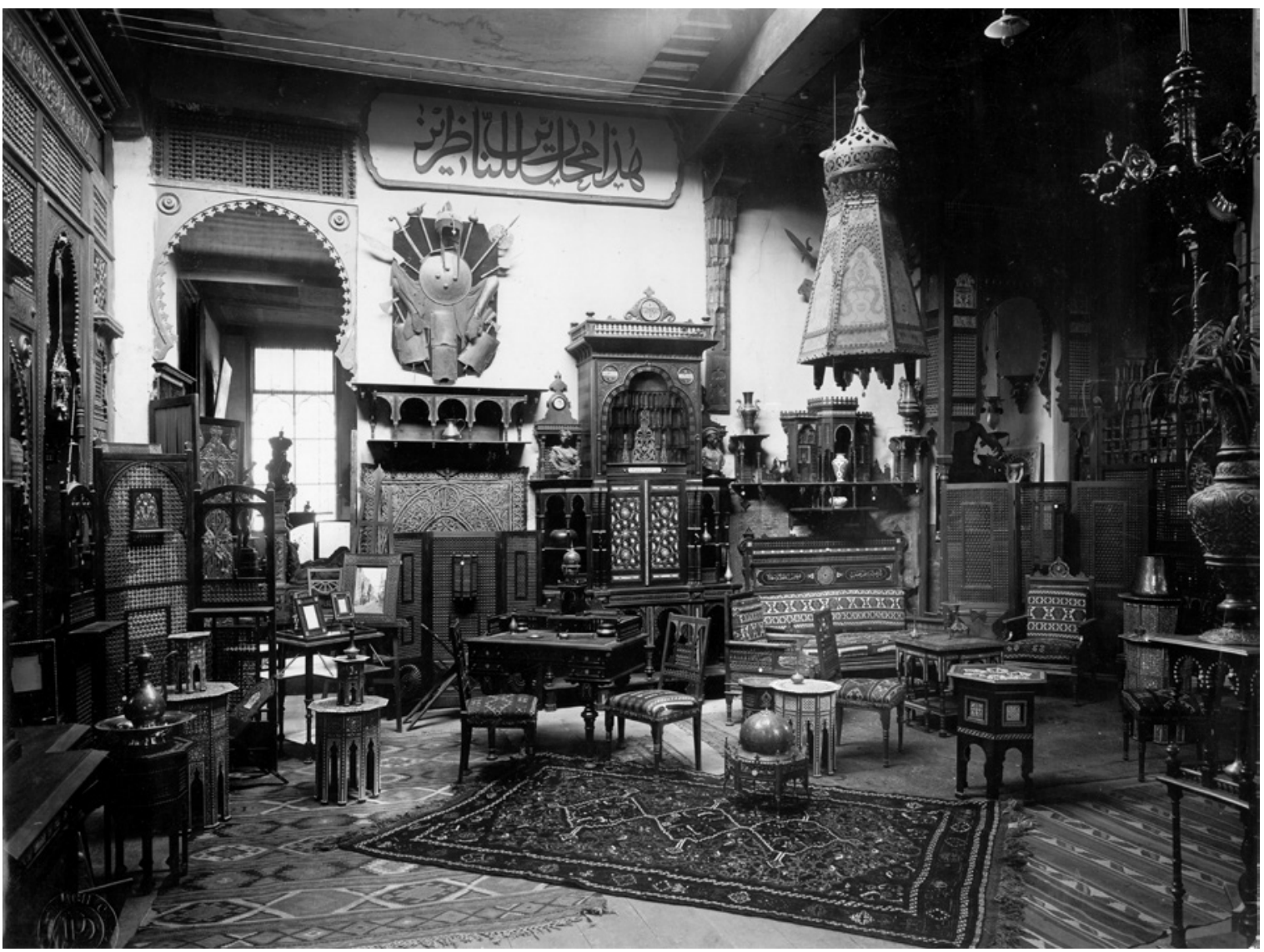

FIGURE 58 Anonymous, Untitled [Parvis's showroom in Cairo, c. 1900]. Albumen print. No dimensions provided ROBERTO PARVIS' PRIVATE COLLECTION

integration into the packaging industry is a significant index of the popularisation achieved by the Middle Eastern stand. ${ }^{109}$ (Fig. 6o) British and American occasional tables also adopted its form. Known examples include a hexagonal table made from stained mahogany, with open arched side panels and bent scrolls, dated c. $1895,{ }^{110}$ and a stream-lined stand from Gustav Stickley's Craftsman Workshop in New York manufactured around 1900. ${ }^{111}$ (Fig. 61)

109 Michael Franklin, British Biscuit Tins (London: Victoria and Albert Museum, 1984).

110 London, Museum of the Home, Hexagonal occasional table, 36/1995. The Tonet-like table inspired by the shape of a kursi was sadly not reproducible at time of going to press.

111 Los Angeles County Museum of Art, "Damascus" Plant Stand, M.200o.186.5a-b.

\section{$3 \quad$ Market Adjustments}

The network of people and situations involved in the trade and consumption of salvage and collectibles in the late Ottoman Eastern Mediterranean delineates a rich panorama that still awaits systematic research. Some sequential order can be attempted from the evidence encountered so far. If there had always been some trade in secondhand goods in Middle Eastern cities, a market for Islamic antiques appears to have been functioning from mid-nineteenth century in Damascus; it developed some two decades later in Cairo. In both cases, antique dealing involved local merchants who had been trading other goods, or had other activities; a number of intermediaries, including hotel managers, also intervened. In this and other respects, antique dealing in the region 


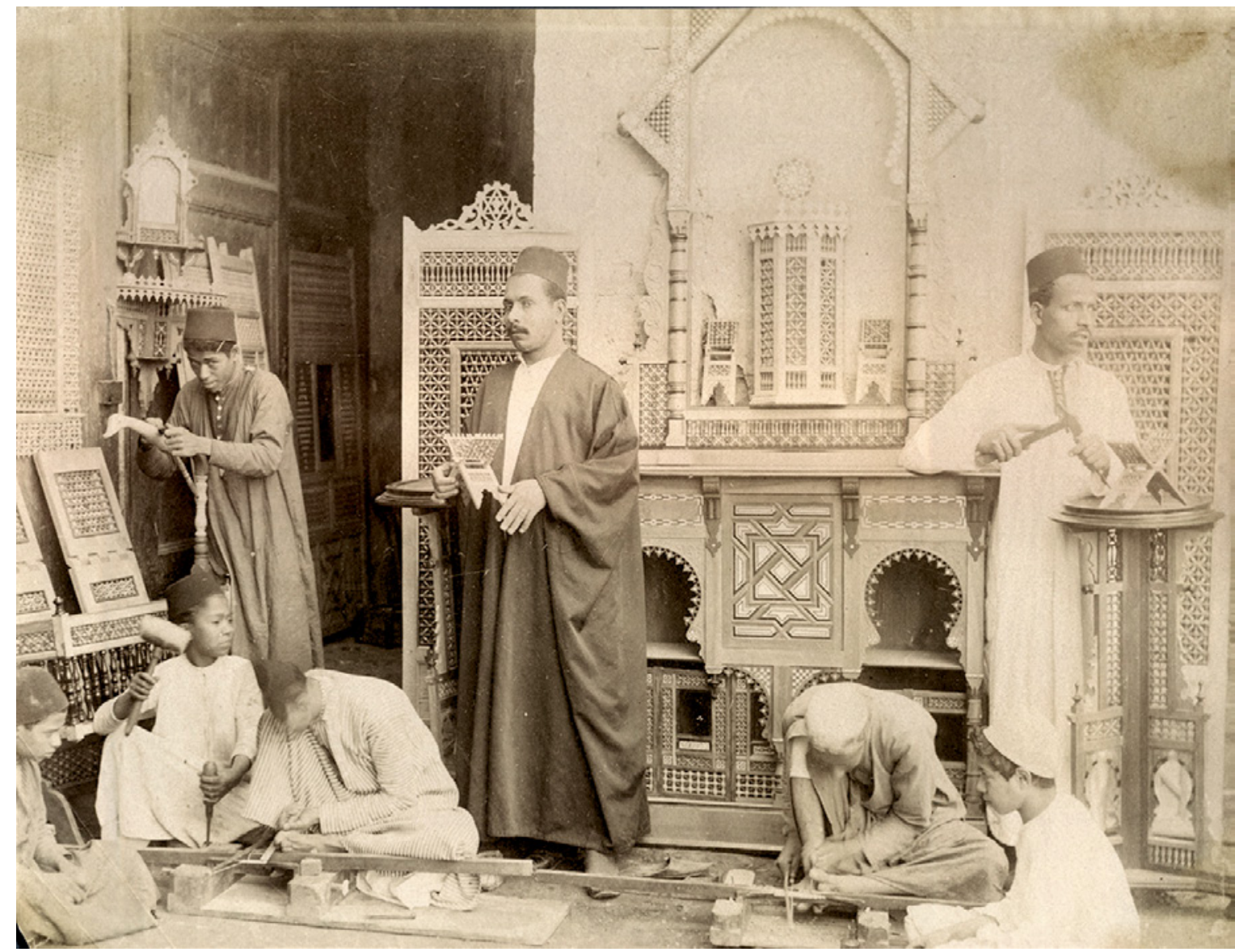

FIGURE 59 Giorgios and Constantinis Zangaki, Menuisiers arabes, c. 189o. [Arab carpenters]. The view was most probably taken at Parvis' workshop, as the large mirror standing in the background very much resembles a model he exhibited in 1878 . Albumen print. $14 \times 18 \mathrm{~cm}$ CURRENT LOCATION UNKNOWN

did not differ much from the situation in Spain, for instance, where the trade in historic decorative artefacts emerged at about the same time and involved similar profiles. ${ }^{112}$ It is important to bear in mind these parallels, when trying to figure out what was happening in the Middle East.

The business attracted foreigners in Egypt, mainly from neighbouring countries such as Greece or Iran, or from more faraway India. The

112 Élodie Baillot, "Réseaux de collectionneurs et enjeux de patrimonialisation en Europe au XIX ${ }^{\mathbf{e}}$ siècle: le baron Davillier, le comte de Valencia de Don Juan et Lady Schreiber" (PhD diss., Paris I University, 2020), 209-40. goods at stake could shift at rapid pace. Metalwork made up a good part of available items in the early days of the antique markets; architectural salvage became predominant from the 1870 , while tiles were not available in vast quantities until a later stage. By the 188 os, the trade in either Cairo or Damascus encompassed the local production of Islamic-style fittings and furnishings.

As a matter of fact, the commerce of curios and the trade in Revival furniture from Cairo and Damascus intersected in many cases. The businesses of the Habras in London and Damascus, Tarazis in Beirut, Gaspare Giuliana in Cairo, as well as stock at the typical Damascene antikji are eloquent examples of overlap. Middle Eastern dealers 


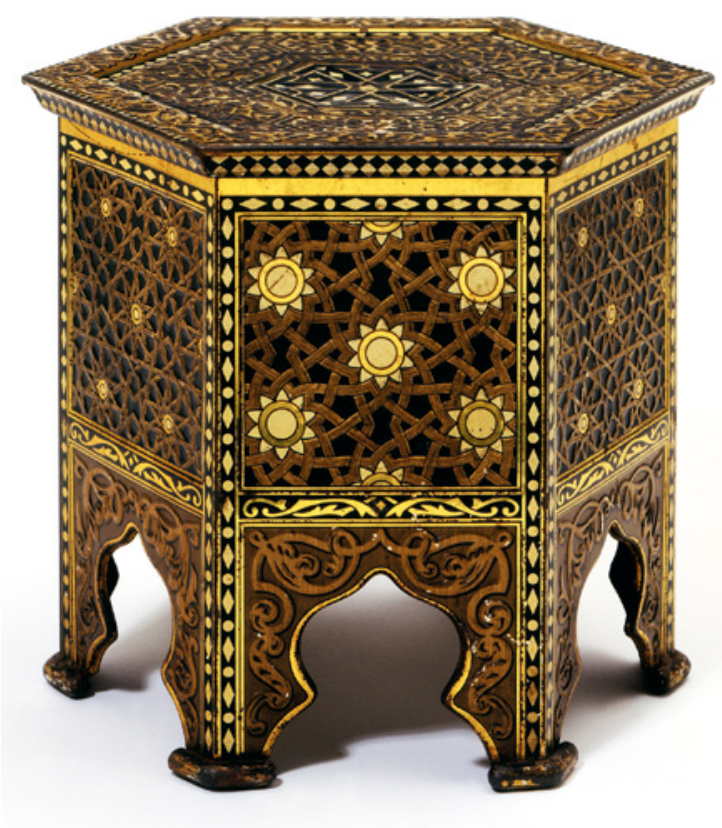

FIGURE 60 A "Syrian" biscuit tin manufactured by Huntley, Boorne \& Stevens for Huntley \& Palmers, 1903. The tin was also produced in a "Cairo" version, and a "Kashmir" one. Offset litho printed tinplate, embossed. $16.6 \times 18.9 \mathrm{~cm}$ LONDON, VICTORIA AND ALBERT MUSEUM, M.297-1983. ON SHOW IN THE BRITISH GALLERIES

were not the only traders operating both commercial lines in the 188 os and 189 os. As mentioned already, an essential part of Liberty and Co's activity in London during its early years was in selling "oriental antiques" besides marketing Eastern imports. Only at a later stage would Liberty turn to British-made "Anglo-oriental furniture" and interiors (see Chapter 4), dropping both commercial lines along the way, once the firm started championing the Art Nouveau crafts for which it is mainly renowned today.

The fate of other regional handicrafts such as embroidery can enrich our understanding of the economics involved. In the second half of the nineteenth century, lace had stimulated a brandnew area of handicraft production in Istanbul. Running out of stock of the old lace sought by

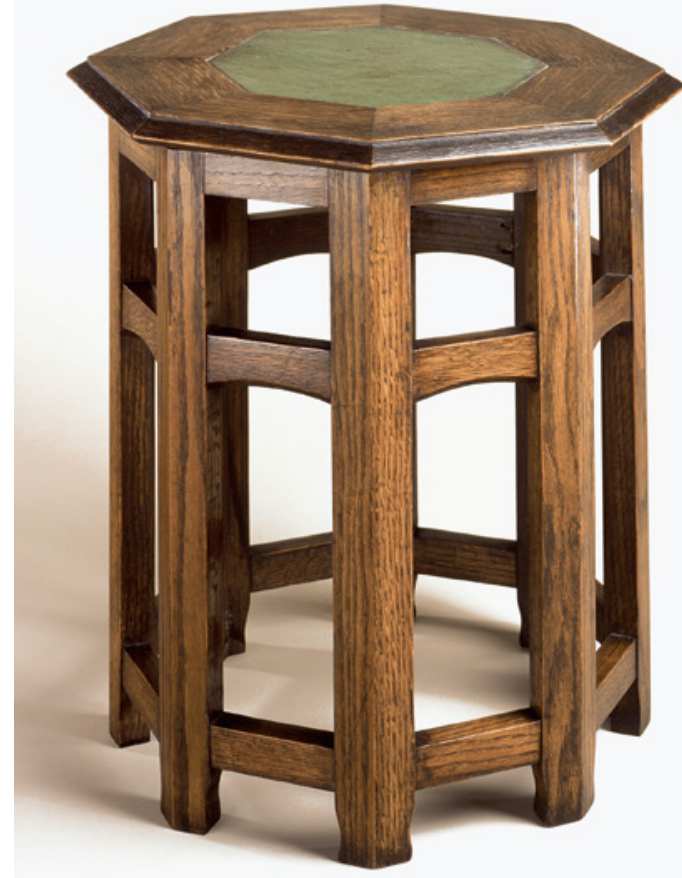

FIGURE 61 Gustav Stickley's Craftsman Workshop, "Damascus" Plant Stand, c. 190o. Oak and earthenware tile. $53.98 \times 50.8 \times 50.8 \mathrm{~cm}$ LOS ANGELES COUNTY MUSEUM, M.2000.186.5A-B. NOT CURRENTLY ON PUBLIC VIEW

European buyers, Istanbul antique dealers fell back to "imitations of the old patterns, and from imitating old patterns, it was one short step to making new patterns," with yarn imported in large quantities from England, Germany and Austria. "This developed into a rather substantial business involving the antique dealers and women embroiderers, working in their own homes."113 The entire production of finished lace was then exported for sale in Paris and London. A reorganised production with new raw material had thus replaced a waning traditional handicraft. An equivalent scenario may have applied to wooden furniture with marquetry, with the additional bonus that it could cater to a domestic demand as well - the kursi and

\footnotetext{
113 Donald Quataert, "Ottoman Handicrafts," 174-75.
} 
related fixtures were also in use locally. As Revival furniture was initially marketed by antique dealers, its industry may have equally resulted from an exhaustion of the authentic product, although, as already seen, the popular tabouret may have had a short history not going back much earlier than the beginning of the nineteenth century.

The intertwining of the trade in antiques with that in Revival crafts was an attempt to respond to the threats posed by European manufacturing and commerce to late Ottoman regional economies. It was a way to expand stock. The double response trading antiques and reviving traditional crafts represents an adjustment to the challenges posed by European exports. The two lines of business were entangled to the point of merging into unique objects: modern furnishings incorporating historic fragments, of which the earlier examples from the region were presented in Paris in 1867 within the framework of the Egyptian participation to the Universal Exposition, by the ruler, as well as the art collector Husayn Fahmi.

The commodification of tangible heritage, to use current idiom, thus constitutes a phenomenon that cannot be reduced to the concept of looting or plunder, despite what is commonly assumed. It partakes in far broader dynamics, fuelled by asymmetrical financial means. While a few Syrian agents, such as the Habras and the Tarazis, managed to go global, the retail processing tended to centralise in British and French hands, demonstrating that European traders were quick in driving the demand to their benefit. By the 188os, some segments of the flow of goods were directly controlled from European capitals, as the case of rugs or woodwork suggests, with their export being encouraged by major Department stores in France and Britain. By 190o, the very best artworks, whether in glass, wood or metal, were not to be acquired in Damascus or Cairo anymore, but at renowned Armenian art dealers in Paris, such as the likes of Dikran Khan Kelekian (1868-1951), Hagop Kevorkian (1872-1962), and Antoine Brimo (of Aleppian descent), as the exceptional Islamic pieces purchased in Paris by amateur Charles Gillot in 1898-1902 demonstrated. ${ }^{114}$

114 Ancienne collection Charles Gillot (183-1903), sale catalogue, Christie's Paris, 4-5 March 2008, 18-30. 